Article

\title{
Comparative Evaluation of Selected Biological Methods for the Removal of Hydrophilic and Hydrophobic Odorous VOCs from Air
}

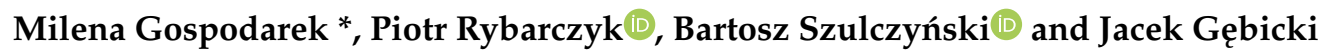 \\ Department of Process Engineering and Chemical Technology, Faculty of Chemistry, \\ Gdańsk University of Technology, Narutowicza 11/12 Street, 80-233 Gdańsk, Poland; \\ piotr.rybarczyk@pg.edu.pl (P.R.); bartosz.szulczynski@pg.edu.pl (B.S.); jacek.gebicki@pg.edu.pl (J.G.) \\ * Correspondence: milena.gospodarek@pg.edu.pl; Tel.: +48-58-347-20-58
}

Received: 8 March 2019; Accepted: 28 March 2019; Published: 1 April 2019

check for updates

\begin{abstract}
Due to increasingly stringent legal regulations as well as increasing social awareness, the removal of odorous volatile organic compounds (VOCs) from air is gaining importance. This paper presents the strategy to compare selected biological methods intended for the removal of different air pollutants, especially of odorous character. Biofiltration, biotrickling filtration and bioscrubbing technologies are evaluated in terms of their suitability for the effective removal of either hydrophilic or hydrophobic VOCs as well as typical inorganic odorous compounds. A pairwise comparison model was used to assess the performance of selected biological processes of air treatment. Process efficiency, economic, technical and environmental aspects of the treatment methods are taken into consideration. The results of the calculations reveal that biotrickling filtration is the most efficient method for the removal of hydrophilic VOCs while biofilters enable the most efficient removal of hydrophobic VOCs. Additionally, a simple approach for preliminary method selection based on a decision tree is proposed. The presented evaluation strategies may be especially helpful when considering the treatment strategy for air polluted with various types of odorous compounds.
\end{abstract}

Keywords: air deodorization; comparison; biofiltration; volatile organic compound; decision tree

\section{Introduction}

\subsection{Air Deodorization by Biological Methods}

Pollution caused by VOCs and other air pollutants, especially odorous compounds, including organic and inorganic compounds, including nitrogen-containing compounds $\left(\mathrm{NH}_{3}\right.$, amines) and sulfur-containing compounds $\left(\mathrm{H}_{2} \mathrm{~S}\right.$, mercaptans, sulfides), have adverse effects on both humans and the environment [1-3]. Odorants have been proven to pose toxic effects on human health as well as to negatively influence the quality of life. Thus, a lot of attention has been devoted to the emission control of VOCs and other odorous pollutants in recent years [4,5].

Odorous compounds are emitted from many sectors of human activity, including wastewater treatment plants, communal waste landfills, agriculture and plenty of industrial facilities e.g., crude oil refineries, pulp and paper mills and various chemical industries. Additionally, the need for indoor air treatment is gaining interest [6-11]. Such emissions are controlled by various deodorization techniques. The following methods are most often applied: thermal oxidation, absorption (in water or with chemical reaction), adsorption, masking and biological techniques. The selection of the most appropriate methods is case-specific and depends on the properties of a gas stream, concentration of pollutants, emission source and the desired level of gas deodorization [1,5,12-15]. 
Among the aforementioned gas deodorization methods, the group of biological methods seems to be superior, especially with the perspective of environment, economy and sustainable development. Biological methods are characterized by low operating costs, low secondary pollution and very high purification efficiency when treating large volumes of gases containing low and medium concentrations of pollutants [16-18]. The process of biological gas treatment is most commonly referred to as "biofiltration". The most common apparatus intended for air biofiltration include conventional biofilters (BF), bioscrubbers (BS) and biotrickling filters (BTF) [19-21]. Beside the differences in the apparatus design, the mechanism of the air treatment process is similar.

The process of biofiltration is based on the degradation of gas contaminants as a result of biological activity of microorganisms inhabiting the porous packing of the biofilter. The microbes are especially present in so-called biofilm developing over the surface of packing elements. The mechanism of the process consists in the diffusion of pollutants from the gas phase to the biofilm surrounded by a liquid phase. This liquid phase may either be supplied as a trickling liquid (biotrickling filter) or may result from former gas humidification (conventional biofilter). Thus, pollutants from the gas phase are either adsorbed on or absorbed by the biofilm and then undergo biodegradation. The stream of treated (cleaned) air leaves the biofilter together with formation of $\mathrm{CO}_{2}, \mathrm{H}_{2} \mathrm{O}$ and biomass as biodegradation products $[5,22,23]$ (Figure 1).

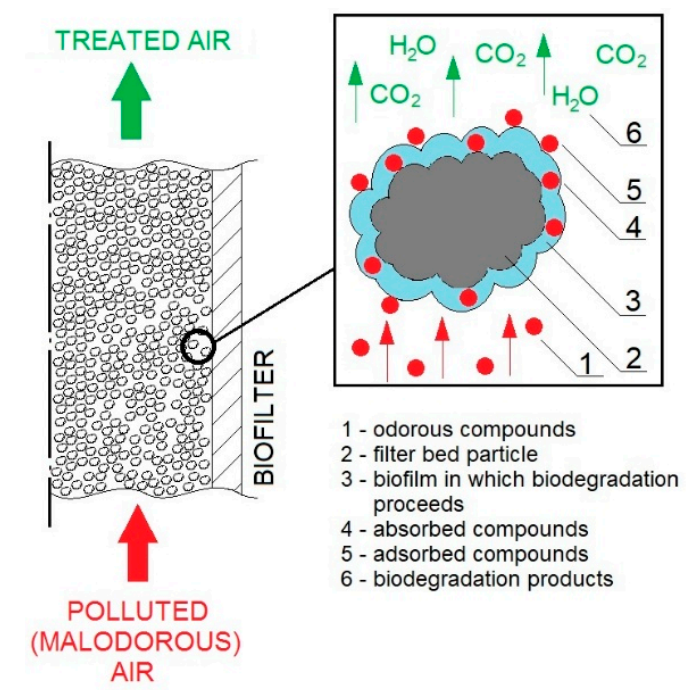

Figure 1. General mechanism of biofiltration.

A conventional biofilter is usually packed with a bed made of organic materials (wood chips, cones, peat) that are naturally colonized by microorganisms capable of degrading various air pollutant impurities. The contaminated gas is humidified in a separate chamber prior to entering the biofilter [24,25].

In the case of BTF, the filter packing is made of inert natural or synthetic materials (ceramic elements, polyurethane foam, lava rock). Such a packing requires inoculation of microbes prior the process start-up and the role of the packing is mainly to give a physical support for the biofilm development. BTF uses a trickling liquid, usually enriched with additional nutrients for microorganisms. Such a configuration enables the pollutants' adsorption/absorption and biodegradation in one apparatus [19,26].

Biological air treatment in bioscrubbers consists in two main processes: absorption of gas contaminants in the liquid phase and biodegradation of these pollutants with the use of additional bioreactors, enabling the liquid regeneration, aeration and circulation [1].

Typical processes of biological air treatment are designed for the removal of water-soluble compounds. The efficiency and the rate of biofiltration of hydrophilic compounds is mainly dependent on the rate of their biodegradation in the biofilm. However, when hydrophobic gas pollutants are considered, the biofiltration efficiency depends drastically on the transfer rate of the components from the gas phase to the liquid, usually aqueous phase [27-29]. This is why biofiltration of hydrophobic 
compounds precedes with much lower efficiency than hydrophilic compounds and currently the improvement of the efficiency of hydrophobic compounds biofiltration is a challenge in the design of the biological treatment processes [16,30].

Depending on the air pollutant type and concentrations, one of above discussed biological treatment methods may be chosen. Biological methods of air treatment have been increasingly investigated since the beginning of the 1990s. Firstly, the research concentrated mainly on the effect of basic parameters on the process performance [5,22,31-33]. Furthermore, more in-depth research on the biological aspects have been developing, including the biotechnological assays for the composition of microbial composition of the biofilm. Currently, the research is focused on the improvement of the removal of hydrophobic air pollutants, biofiltration of which is usually limited by low mass transfer rate from the gas to the liquid (biofilm) phase. Parallel to typical experimental investigations, also in the semi-pilot and pilot scales, modeling of these processes is investigated and developed [34-37]. Examples of the latest research include the application of fungi for biofiltration [38], modeling of serial biofiltration unit [39], upgrading of biogas in biofilters [40] or biomass overgrowth control strategies [41]. Research in the field of biotrickling filtration is devoted to e.g., small-scale applications for indoor air treatment [42], application of new strands of microbes [43] or process scaling-up [44]. Examples of current research on bioscrubbers are the emission control of $\mathrm{NH}_{3}$ from agricultural applications [45] or treatment of air polluted with H2S and others [46-48].

The selection of the most suitable treatment method is a function of several factors, especially when mixtures of hydrophilic or hydrophobic compounds are considered. In this perspective, a broad set of data or mathematical tools aiding the decision-making may be of importance. In the literature, several papers devoted to comparison of various deodorization methods [12,49-51] may be found. However, these papers mainly present the experimental results and economic analyses or compares different processes/process conditions, leaving the reader with general ideas about the processes discussed. Therefore, the development of a comparative tool for the selection of the treatment method is of both scientific and practical importance.

\subsection{Assessment of Biological Methods of Air Treatment}

In this paper, two approaches of comparative analysis or selection criteria for the treatment of air polluted with various volatile compounds are investigated. An evaluation methodology based on the procedure described by Oliva et al. [15] is proposed in this paper. The adopted method is derived from a pairwise comparison model, using numerical judgments from an absolute scale of numbers. This method was initially proposed by Henri Lebesgue and it enables the comparison of the examined objects, with the aid of the analysis of their properties and selection of the appropriate scale [52]. It is based on comparing elements, in order to receive their assessment, based on a preference. This method also allows to choose which of the analyzed elements are characterized by a larger number of the selected quantitative properties. Pairwise comparison is often a crucial step in multi-criteria decision analysis [53]. This method was chosen due to the fact that it allows for a fair division and balance of the final value into individual components [54,55]. Similar comparisons are made in other fields of science, e.g., assessment of fuels [56], voting system [57-59], psychology [60,61], artificial intelligence system [62] and others [63-65]. They key element is to provide a tool for making an objective comparison taking into account the division into various aspects of a given field.

Additionally, a decision tree procedure for the selection of a treatment technology is proposed. Decision tree is a graphical method of supporting the decision-making process, which can be used for different types of modeled variable, i.e., continuous or discrete. The goal is to create a model that predicts the value of a target variable based on several input variables $[66,67]$. The main task of the decision tree method is to generate mutually exclusive regions in which there are as many samples as possible classified into one group. These regions are created by successive divisions of the training set, using binary logical rules [68]. The learning process is carried out to obtain the most homogeneous group of sample sets. As an algorithm output, decision trees can provide two types of information: 
the description of which group the examined object is located in or the probability of belonging to a given group [69].

\subsection{Aim of Investigations}

The aim of this paper is to provide a comprehensive assessment of the selected biological methods for the removal of various volatile compounds from air i.e., biofiltration, biotrickilng filtration and biscrubbing with the use of a pairwise comparison model as well as decision tree procedure.

This paper presents three interesting elements from the novelty viewpoint. Firstly, the paper revises the results of selected recent research on the application of biological methods for selected air pollutants, thus it may serve as a source of experimental results. Secondly, the authors adopted a comparison procedure for evaluating the holistic effects of performance, costs and technical aspects of treating air with a given method. Thirdly, a simple tool for preliminary selection of the method is proposed. Such an approach is hardly met in the literature and presents useful way of comparing processes.

\section{Materials and Methods}

\subsection{Data Collection}

For the purpose of calculations for a pairwise model as well as the development of a decision tree, literature data was used. For literature search, Science Direct, PubMed and MDPI databases were applied. Articles from last 10 years were selected with the priority of choosing, however older articles were used as well (depending e.g., on the target chemical compound in a given treatment method). Selection of literature data was applied according to the target compound so as to collect data suitable for comparison purposes. Data applied in calculations were taken directly from the literature without normalization procedures.

\subsection{Comparative Analysis}

A comparative analysis of biological methods in the perspective of the removal of hydrophilic, hydrophobic or inorganic odorous gases is presented with the use of a pairwise comparison model [52]. The numerical procedure used is based on the quantification of a set of parameters previously classified in clusters. It is used to select the best biological process of air purification from impurities. The results obtained on the basis of the semi-quantitative ranking of selected parameters pointed to the advantages and disadvantages of the processes studied. For the purpose of comparison, the focus is on the process performance, technical, economic as well as environmental aspects. The applied method consists in assigning specific values to all highlighted alternatives. Calculations are realized in four main stages i.e., selection of the main criteria determining the deodorization process $\left(C_{1}-C_{4}\right)$ as well as selection of sub-criteria affecting the main criteria $\left(\mathrm{C}_{1.1}-\mathrm{C}_{4.2}\right)$; assigning weights to each criterion and sub-criterion $\left(w_{i}\right.$ and $\left.w_{i j}\right)$; assigning indicators to sub-criteria (values in the range between 0 and 1 ); calculation of the results of all alternatives.

The results of all alternatives were obtained using the following equations [28]:

$$
\begin{gathered}
R_{i}=w_{i, j 1} \cdot r_{i, j 1}+w_{i, j 2} \cdot r_{i, j 2}+\ldots+w_{i, j n} \cdot r_{i, j n} ; i=1, \ldots, n ; j=1, \ldots, n \\
R=w_{i 1} \cdot R_{i 1}+w_{i 2} \cdot R_{i 2}+\ldots+w_{i n} \cdot R_{i n} ; i=1, \ldots, n ; j=1, \ldots, n
\end{gathered}
$$

where:

$w_{i, j}$ - weight of a given sub-criterion $\mathrm{C}_{\mathrm{i}, \mathrm{j}}$,

$r_{i, j}$ - result of an alternative to the sub-criterion $\mathrm{C}_{\mathrm{i}, \mathrm{j}}$,

$R_{i}$ - result of an alternative to the criterion $\mathrm{C}_{\mathrm{i}}$,

$w_{i}$ - weight of given criterion $\mathrm{C}_{\mathrm{i}, \mathrm{j}}$, 
$R$ - overall result of the alternative,

$n$ - number of analyzed criteria.

\subsection{Decision Tree for the Preliminary Selection of the Deodorization Method}

In the second part of this paper, a decision tree procedure was applied. The decision tree has been built based on data from 57 biological processes of removing various chemical compounds from the air i.e., conventional biofiltration, biotrickling filters and bioscrubbers. The data set is presented in Table 5 . The following process parameters were selected as input variables: inlet concentration, Henry's constant and empty bed residence time (EBRT). As the result of the decision tree, the most optimal air purification method may be indicated. All calculations were performed in RStudio 1.1.463 [70] using the 'rpart' library [71].

The main advantages of using decision trees are their non-parametric character as well as the automatic identification of the most significant variables by the algorithm and the elimination of statistically insignificant variables. Moreover, the mathematical transformation (e.g., logarithm) of one or more explanatory variables does not change the structure of the tree which is changed only by threshold values. Among the disadvantages should be indicated: a slight modification of the training set (e.g., removal of several observations) can radically change the structure of the tree. In addition, in one step the tree can divide the space only in relation to one variable (in other words: the dividing lines are always perpendicular to the divided axis in the variable space).

\subsection{Calculation of Process Performance Parameters}

Removal efficiency and empty bed residence time were selected as parameters presenting process performance. These parameters indicate both the degree of the removal of odorous compounds from air as well as gives the information about the rate of the process course based on the air flow rate and the capacity of a bioreactor. Values of RE and EBRT were either taken directly from literature data or calculated according to Formulae (3) and (4):

$$
\begin{gathered}
\mathrm{RE}=\left(\frac{\mathrm{C}_{\text {in }}-\mathrm{C}_{\text {out }}}{\mathrm{C}_{\text {in }}}\right) \cdot 100 \% \\
\mathrm{EBRT}=\frac{\mathrm{V}}{\mathrm{Q}}
\end{gathered}
$$

where:

$\mathrm{C}_{\text {in }}$ - inlet concentration of target compound,

$\mathrm{C}_{\text {out }}$ - outlet concentration of target compound,

$\mathrm{V}$ - volume of the filter bed,

Q - inlet gas flow rate.

\section{Results and Discussion}

\subsection{Selection of Comparison Main Criteria}

In order to characterize biological methods of air deodorization, four main criteria were selected: efficiency/process performance, costs, technical aspects and problems as well as the environmental impact. The aforementioned criteria have been chosen in the perspective of possibly complete evaluation of each analyzed treatment method. The selection criteria are presented in Figure 2. 


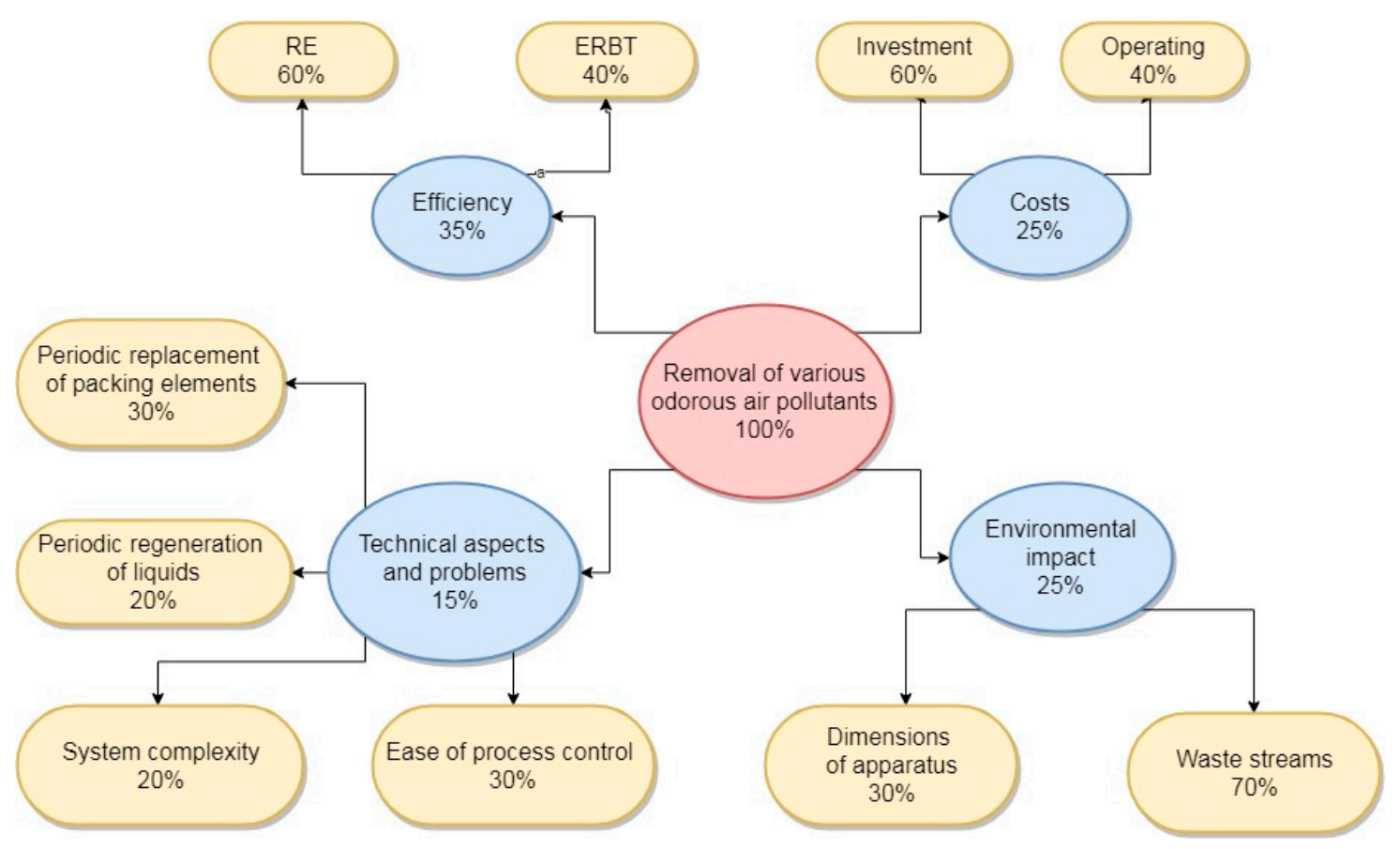

Figure 2. Hierarchy of selected criteria and sub-criteria.

Each of the selected criteria has been divided into second-order criteria. As part of the performance criterion, two sub-criteria were distinguished: removal efficiency (RE) and empty bed residence time (EBRT) $[1,4,5,72]$. Values of RE inform about the degree of air purification and enable to differentiate among the process performance of analyzed methods. Comparison of the values of empty bed residence time allows for the assessment of the rate of the assessed treatment processes. The criterion related to the costs include investment and operating costs as sub-criteria $[12,19,73,74]$. These costs are crucial for the process realization, especially when industrial-scale applications are considered.

The authors of this manuscript have proposed two more criteria related to the deodorization strategy i.e., technical problems arising during the process $[1,5,19,20,31]$ as well as the environmental impact of the technology [12,73-75]. Among the technical aspects and possible technical problems, which are thought to greatly affect the long-term process operation, following sub-criteria have been distinguished: periodic replacement of packing elements, the need for periodic regeneration of the liquid, the complexity of the system, as well as the ease of process control and the ability to adapt the system to changes in the charge of current regulation. These sub-criteria have been proposed based on a literature review.

The following sub-criteria have been proposed when the environmental impact of the deodorization technique is considered: dimensions of the apparatus and waste streams generated during the treatment process. Depending on the flow rate of treated air streams, the dimensions of the apparatus may greatly differ (laboratory to industrial scale) [75]. In this perspective, conventional biofilters, especially the open-type, occupy plenty of land area, resulting in a high foot-print. Sizes of biotrickling filters are much smaller. On the other hand, the operation of bioscrubbers generates high volumes of liquid containing compounds absorbed from air and these liquid streams must be further processed $[1,5]$. This is why the sub-criteria including apparatus size and waste streams generation have been proposed.

\subsection{Assigning of Weights to Criteria and Sub-Criteria}

The choice of criteria and sub-criteria was made on the basis of a literature review. A literature review was prepared using peer-reviewed journals, other professional literature [72] as well as conference materials. When choosing and proposing the values of the criteria, the authors took 
advantage of the process experience of the team $[13,21,25,76]$. Having the above set of data, the authors attributed the criteria and sub-criteria to the weights, reflecting the importance of the aspect to the entire process of biological purification of air from pollutants. The values of weights are given in Table 1.

Table 1. Weight of the criteria and sub-criteria and ranges of sub-criteria indicators.

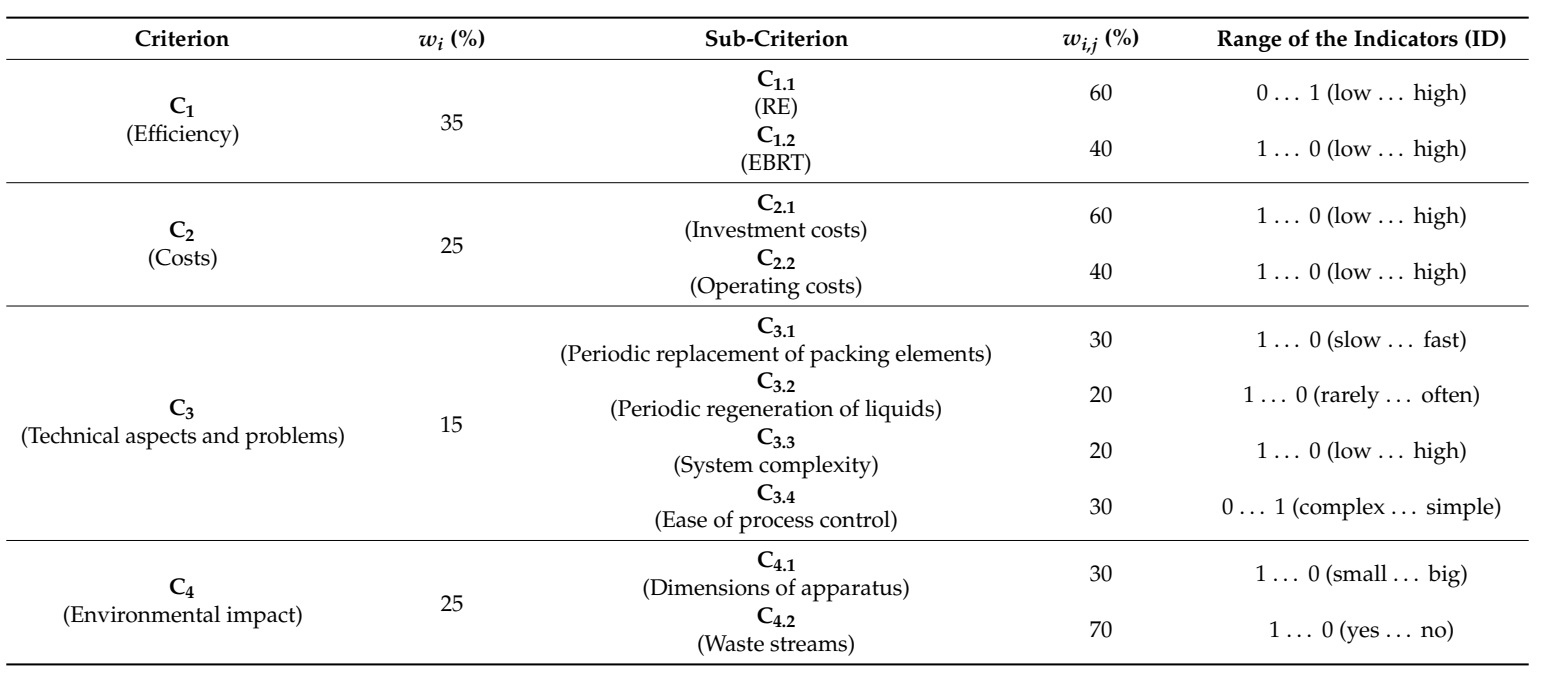

\subsection{Assigning of Indicators}

Based on the literature data presented in Table 2; in Table 3, indexes were assigned to indicators taking into account the "bigger is better" principle, i.e., values were assigned from the range from 0 to 1 , where the value of 1 is the most favorable considering the whole group of analyzed methods, as given in Table 2. Each criterion and sub-criterion has been transformed into an indicator (values assigned to sub-criteria $\mathrm{C}_{1.1}-\mathrm{C}_{4.2}$ ).

The differences in the hydrophilic character of the compounds were estimated using Henry's law constant. The greater the Henry's law constant, the greater the volatility and the lower the solubility of a compound, which is valid for dilute solutions and non-reacting gases at near ambient pressure and temperature. The Henry's law constant $\left(\mathrm{H}_{\mathrm{c}}\right)$ can be expressed as the dimensionless ratio between the aqueous-phase concentration $C_{a}$ of a species and its gas-phase concentration $C_{g}$ [77]:

$$
\mathrm{H}_{\mathrm{C}}=\frac{\mathrm{C}_{\mathrm{g}}}{\mathrm{C}_{\mathrm{a}}}
$$

Taking into account Equation (4), values of dimensionless Henry's constant in Table 2 were calculated using Formula (5):

$$
\mathrm{H}_{\mathrm{C}}=\frac{\mathrm{RF}}{\mathrm{H}}
$$

where:

$\mathrm{RF}$ - recalculation factor equal to $4.03395 \times 10^{-4}$, taken from [77],

$\mathrm{H}$ - Henry's constant given as $\left(\mathrm{mol} \cdot \mathrm{m}^{-3} \cdot \mathrm{Pa}^{-1}\right)$ in Table 2. 
Table 2. Literature data for determining the values of sub-criteria 1.1 and 1.2.

\begin{tabular}{|c|c|c|c|c|c|c|c|c|c|c|c|c|c|c|}
\hline \multirow[b]{2}{*}{ Compounds } & \multirow[b]{2}{*}{$\frac{\mathrm{H}}{\left(\mathrm{mol} \cdot \mathrm{m}^{-3} \cdot \mathrm{Pa}^{-1}\right)}$} & \multirow[b]{2}{*}{$\mathbf{H}_{\mathrm{c}}(-)$} & \multicolumn{4}{|c|}{ Conventional Biofilter } & \multicolumn{4}{|c|}{ Biotrickling Filter } & \multicolumn{4}{|c|}{ Bioscrubber } \\
\hline & & & $\begin{array}{c}\mathrm{C}_{\mathrm{in}} \\
\left(\mathrm{mg} \cdot \mathrm{m}^{-3}\right)\end{array}$ & RE (\%) & EBRT (s) & Reference & $\begin{array}{c}\mathrm{C}_{\text {in }} \\
\left(\mathrm{mg} \cdot \mathrm{m}^{-3}\right)\end{array}$ & RE (\%) & EBRT (s) & Reference & $\begin{array}{c}\mathrm{C}_{\mathrm{in}} \\
\left(\mathrm{mg} \cdot \mathrm{m}^{-3}\right)\end{array}$ & RE (\%) & EBRT (s) & Reference \\
\hline Hydrophilic & - & - & - & 99 & - & [73] & - & 99 & - & [73] & - & 99 & - & [73] \\
\hline butanol & $1.2[77]$ & $3.4 \times 10^{-4}$ & $900-2600$ & $>73$ & 60 & [78] & $400-1200$ & $15-99$ & $60-124$ & [79] & - & 98-100 & 48 & [80] \\
\hline aniline & $1.1[5]$ & $3.7 \times 10^{-4}$ & - & - & - & - & 300 & $<99$ & $42-166$ & [81] & - & - & - & - \\
\hline isopropanol & $1.3[77]$ & $3.1 \times 10^{-4}$ & $1000-8000$ & 81 & 94.2 & [82] & $\begin{array}{c}20-65 \\
\left(\mathrm{~g} \mathrm{~m}^{-3} \cdot \mathrm{h}^{-1}\right)\end{array}$ & $<95$ & $14-160$ & [83] & $200-500$ & 99 & - & [84] \\
\hline ethanol & $9.0[77]$ & $4.5 \times 10^{-5}$ & 3700 & 63-85 & 101 & [85] & 470 & $\sim 80$ & 66 & [86] & & $80-99$ & - & [87] \\
\hline methanol & $2.0[77]$ & $2.0 \times 10^{-4}$ & $\begin{array}{c}- \\
0.79-3.3\end{array}$ & $\begin{array}{l}>95 \\
93.33\end{array}$ & $\begin{array}{l}25 \\
38\end{array}$ & $\begin{array}{l}{[88]} \\
{[91]}\end{array}$ & $300-37,000$ & 65 & $20-65$ & [89] & $\begin{array}{c}50-100 \\
-\end{array}$ & $\begin{array}{c}69-81 \\
75\end{array}$ & $\begin{array}{l}600 \\
2.5\end{array}$ & $\begin{array}{l}{[90]} \\
{[92]}\end{array}$ \\
\hline Hydrophobic & - & - & & 75 & - & [73] & - & 50 & - & [73] & - & 50 & - & [73] \\
\hline hexane & $6.1 \times 10^{-3}[77]$ & $6.6 \times 10^{-2}$ & $\begin{array}{l}500-11,000 \\
200-10,000\end{array}$ & $\begin{array}{c}79 \\
59-76\end{array}$ & $\begin{array}{l}60 \\
60\end{array}$ & {$\left[\begin{array}{l}{[93]} \\
{[95]}\end{array}\right.$} & 600 & $57-91$ & $8-30$ & [94] & 6200 & 70 & 420 & [92] \\
\hline methane & $1.4 \times 10^{-5}[77]$ & $2.9 \times 10^{-1}$ & $4581-4908$ & 43 & 257 & [96] & $0-500$ & $\sim 40$ & 240 & [97] & - & $5-25$ & 1.6 & [98] \\
\hline ethylene & $5.9 \times 10^{-5}[77]$ & 6.8 & 331 & 100 & 2160 & [99] & $\begin{array}{c}8-100 \\
\left(\mathrm{~g} \mathrm{~m}^{-3} \cdot \mathrm{h}^{-1}\right)\end{array}$ & $70-95$ & 30 & {$[27,100]$} & - & - & - & - \\
\hline$\alpha$-pinene & $2.9 \cdot \times 10^{-4}[77]$ & 1.4 & $\begin{array}{c}100-450 \\
4227\end{array}$ & $\begin{array}{c}90 \\
47-67\end{array}$ & $\begin{array}{l}42 \\
78\end{array}$ & $\begin{array}{l}{[101]} \\
{[103]}\end{array}$ & - & - & $14-60$ & [102] & - & - & - & - \\
\hline styrene & $2.7 \times 10^{-3}[77]$ & $1.5 \times 10^{-1}$ & $0.1-0.9$ & 90 & $9-18$ & [104] & $800-3300$ & 95 & $60-120$ & [105] & - & - & - & - \\
\hline & & & $\begin{array}{l}0.85 \\
2.3\end{array}$ & 97 & 1845 & {$[106]$} & 55-312 & 90 & $15-30$ & [107] & - & - & - & - \\
\hline toluene & $1.5 \times 10^{-3}[77]$ & $2.7 \times 10^{-1}$ & $\begin{array}{c}2.5 \\
1.9 \\
6\end{array}$ & $\begin{array}{l}>80 \\
<98\end{array}$ & $\begin{array}{c}13-820 \\
21.6 \\
70\end{array}$ & {$\left[\begin{array}{l}{[108]} \\
{[113]}\end{array}\right.$} & $\begin{array}{l}2-1128 \\
2200 \\
1000\end{array}$ & $\begin{array}{c}99 \\
<99 \\
60\end{array}$ & $\begin{array}{c}400 \\
16.2 \\
57\end{array}$ & $\begin{array}{l}{[109]} \\
{[112]} \\
{[114]}\end{array}$ & 3300 & 89 & - & [110] \\
\hline Inorganic & & & & & & & & & & & & & & \\
\hline ammonia & $5.5 \times 10^{-1}[77]$ & $7.3 \times 10^{-4}$ & 14-350 & 92-100 & 17 & [115] & $\begin{array}{c}9.6 \\
20-100\end{array}$ & $\begin{array}{l}82 \\
99\end{array}$ & $\begin{array}{l}1.2 \\
960\end{array}$ & $\begin{array}{l}{[116]} \\
{[118]}\end{array}$ & 14 & 99 & 142 & [117] \\
\hline $\mathrm{H} 2 \mathrm{~S}$ & $1.0 \times 10^{-3}[77]$ & $4.0 \times 10^{-1}$ & $7-3750$ & 100 & 23-200 & [119] & $300-650$ & 65-100 & $53-79$ & [120] & $14-140$ & 98 & $12-32$ & [47] \\
\hline
\end{tabular}


Table 3. Literature data for determining the values of sub-criteria 2.1-4.2 (investment and operating costs are presented for a flowrate $50,000 \mathrm{~m}^{3} \mathrm{~h}^{-1}$ ).

\begin{tabular}{|c|c|c|c|c|c|c|}
\hline & Criteria and Sub-Criteria & Units & BF & BTF & Refe & \\
\hline 2 & \multicolumn{6}{|c|}{ Costs } \\
\hline \multirow{3}{*}{2.1} & \multicolumn{6}{|c|}{ Investment } \\
\hline & & $\left(€\right.$ per $\left.\mathrm{m}^{3} \cdot \mathrm{h}^{-1}\right)$ & 6 & 11 & 4 & [73] \\
\hline & & $\left(€\right.$ per $\left.\mathrm{m}^{3} \cdot \mathrm{h}^{-1}\right)$ & 5 & 10 & 4 & [12] \\
\hline \multirow{3}{*}{2.2} & \multicolumn{6}{|c|}{ Operating } \\
\hline & & $\left(€\right.$ per $\left.\mathrm{m}^{3} \cdot \mathrm{h}^{-1}\right)$ & 2 & 1.2 & 3.6 & [74] \\
\hline & & $\left(€ \cdot 10^{-4} \cdot \mathrm{m}^{-3}\right)$ & 0.2 & 0.1 & 0.28 & [73] \\
\hline 3 & \multicolumn{6}{|c|}{ Technical aspects and problems } \\
\hline \multirow{4}{*}{3.1} & \multicolumn{6}{|c|}{ Periodic replacement of element } \\
\hline & Packing material & (years) & 2 & 10 & 10 & [73] \\
\hline & Annual/material-reagents & $\left(\mathrm{kg} \mathrm{m}^{3} \cdot \mathrm{h}\right)$ & 4 & 0.1 & 0.1 & [73] \\
\hline & Packing material & $(\%)$ & 47 & 44 & 4 & [74] \\
\hline \multirow{3}{*}{3.2} & \multicolumn{6}{|c|}{ Periodic regeneration of liquids } \\
\hline & Annual water consumption & $\left(\mathrm{L} \cdot \mathrm{m}^{-3} \cdot \mathrm{h} \cdot 10^{2}\right)$ & 2.4 & 6.3 & 3.3 & [73] \\
\hline & $\begin{array}{l}\text { Water that can be replaced } \\
\text { with secondary effluent }\end{array}$ & $(-)$ & Possible & Possible & Impossible & [73] \\
\hline \multirow{3}{*}{3.3} & \multicolumn{6}{|c|}{ Complexity of the system } \\
\hline & $\begin{array}{c}\text { Basic elements of } \\
\text { the apparatus }\end{array}$ & $(-)$ & $\begin{array}{l}\text {-Humidification chamber } \\
\text {-Packed bioreactor }\end{array}$ & $\begin{array}{l}\text {-Packed bioreactor } \\
\text {-Liquid container } \\
\text {-Pump }\end{array}$ & $\begin{array}{c}\text {-Absorption column } \\
\text {-Pump } \\
\text {-Absorbent tank }\end{array}$ & [5] \\
\hline & $\begin{array}{l}\text { number of basic elements of } \\
\text { the apparatus }\end{array}$ & $(-)$ & 2 & 3 & 3 & $(-)$ \\
\hline \multirow{3}{*}{3.4} & \multicolumn{6}{|c|}{ Ease of process control } \\
\hline & impact on the control process & $\mathrm{V}$ & Low & High & Medium & $(-)$ \\
\hline & Customization at work & $(-)$ & Impossible & High & Medium & $(-)$ \\
\hline 4 & \multicolumn{6}{|c|}{ Environmental impact } \\
\hline \multirow{3}{*}{4.1} & \multicolumn{6}{|c|}{ Dimensions of the apparatus } \\
\hline & The size of the apparatus & {$\left[\mathrm{m}^{2} \cdot \mathrm{m}^{-3} \cdot \mathrm{h} \cdot 10^{2}\right]$} & 1.75 & 0.25 & 0.1 & [73] \\
\hline & Surface area & $(-)$ & High & Low & Low & [87] \\
\hline \multirow{5}{*}{4.2} & \multirow{5}{*}{$\begin{array}{l}\text { Use of filling } \\
\text { The possibility of replacing } \\
\text { water with sewage } \\
\text { Volume of liquid }\end{array}$} & & Waste streams & & & \\
\hline & & $(-)$ & Possible & Impossible & Impossible & [73] \\
\hline & & $(-)$ & Possible & Possible & Impossible & [12] \\
\hline & & vol $<<$ VOL & - & vol & VOL & [12] \\
\hline & & - & Very low & Medium & High & {$[-]$} \\
\hline
\end{tabular}

The values of indicators (Figure 3) are proposed and derived from data presented in Table 2; Table 3 as well as additional literature data $[1,19,20,31]$.

The values of indicators for investment and operating costs are presented in Figure 3a. The obtained results indicate that BSs are characterized by the lowest investment costs (ID = 1), while the highest investment costs are found for BTFs (ID $=0.3$ ). Such a result may be justified by the number of basic elements of apparatus included in the system (BTF contains the highest number of elements, i.e., biofilter chamber, packed bed, circulating pumps, liquid containers, trickling system).

Interestingly, the lowest operating costs are associated with BTF operation (ID =1), while the highest are attributed to bioscrubbers. The operating costs of BFs (ID $=0.66)$ are medium in the compared group of methods. It mainly results from the periodic maintenance requirements, as described more precisely by the technical-aspects-and-problems sub-criterion. The BS process is associated with the highest operating costs (ID $=0.33$ ).

Figure $3 \mathrm{~b}$ shows the values of indicators for periodic replacement of packing elements, periodic regeneration of liquid, complexity of the system and possibility of process control. The literature indicates that the packing material in BTF (ID =1) should be replaced the least frequently. It is mainly because of the fact that inert, ceramic or synthetic materials are applied as packing materials and their durability is much higher than for natural packing materials, used in BFs [1,5]. By contrast, the results indicate that $\mathrm{BF}$ requires the most frequent replacement of the packed bed $(\mathrm{ID}=0.2)$ because $\mathrm{BFs}$ are usually packed with natural organic packing materials. The replacement of liquid, due to apparatus construction, does not typically apply for BF (ID =1). Interestingly, in terms of BS and BTF it is possible to replace water with so called secondary wastewater [73]. Periodic liquid replacement is the biggest problem in the case of BS (ID = 0.3), despite the fact that water consumption compared to the other two processes is at an average level. This results from the inability to use "wastewater" for secondary 
use. BTF and BS are characterized by the greatest complexity of the system (ID $=0.8)$. They have three or more basic elements of the apparatus (e.g., bioreactors, packing elements, pumps, trickling system, absorption column etc.). $\mathrm{BF}$, on the other hand, is a relatively simple system (ID =1), having only two basic elements in its construction (humidification chamber and biofilter itself).

(a)

a)

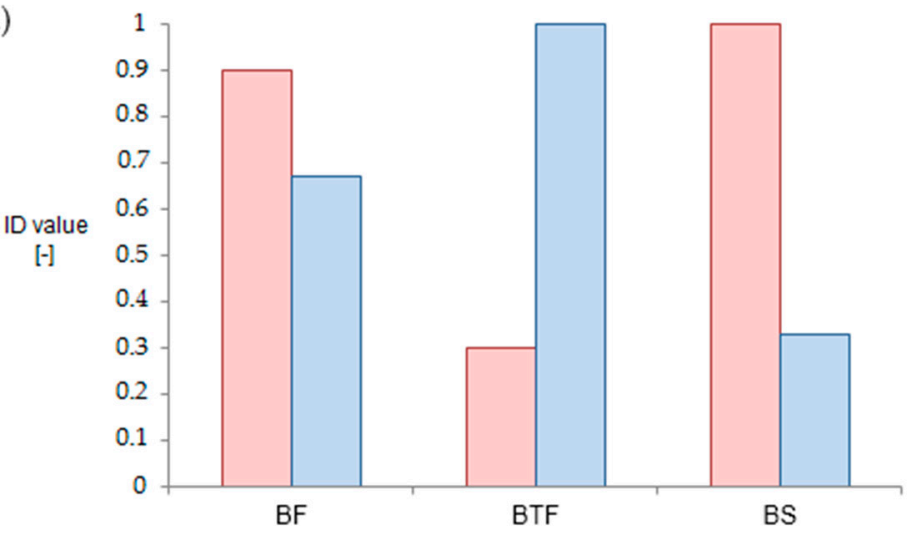

口Investment costs

口Operating costs

(b)

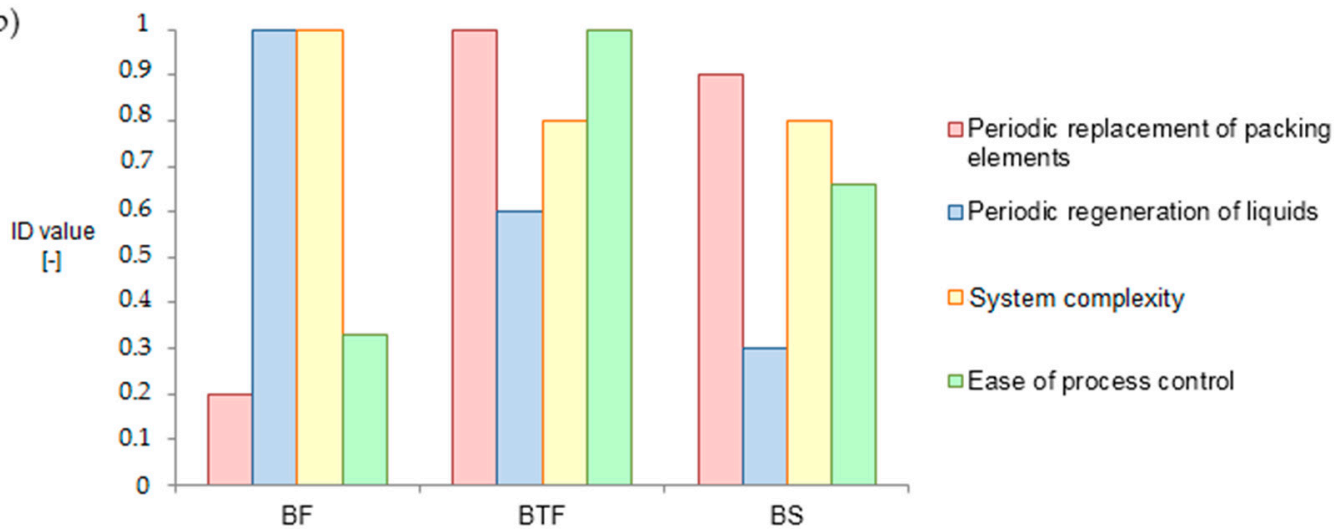

(c)

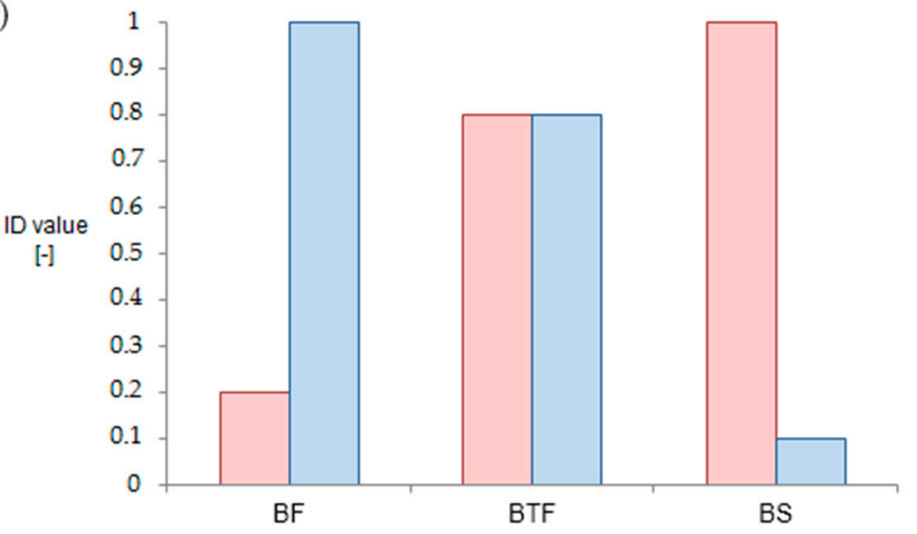

$\square$ Dimensions of apparatus

$\square$ Waste streams

Figure 3. Diagrams presenting indicator values for each sub-criterion: (a) diagram of criterion 2.

(b) diagram of criterion 3. (c) diagram of criterion 4 .

The results regarding the possibility of a system control indicate that BTFs are characterized with ID $=1$. This is because this treatment method enables the application of the most complex, effective and quickly responding control system (e.g., control and regulation of trickling liquid frequency, $\mathrm{pH}$, flow rate or composition) [5,31]. The control of process realized in BS is much lower (ID $=0.67)$ and the lowest control possibility is for BF (ID = 0.33), indicating high inertness of the process and little regulation possibility in the case of conventional biofilters. 
The size of the apparatus (both occupied surface area and capacity) is the largest for BF and this is why the ID calculated for $\mathrm{BF}$ is equal to 0.2 (ID =0.2) (Figure 3c). BS has the smallest area occupied by the apparatus (ID =1), however the volume of liquid used for the BS process is high. The amount of waste produced is the smallest in the case of BF (ID =1). Additionally, further reuse of packing material (for anther purposes e.g., land fertilizers) as well as the replacement of water by secondary water [12] is possible. The least favorable method in terms of generation of waste streams is BS (ID = 0.1), indicating the need of further processing of generated wastewater for the recovery of absorbed compounds as well as down-stream water purification.

\subsection{Results of a Pairwise Comparison}

Table 4 was prepared in order to summarize the results collected during a pairwise evaluation procedure. The results contained therein q compare the cost-effectiveness of each analyzed method, in general, as well as the given criterion. Table 4 presents the aggregated results for the criterion (C1-C4) and overall result of the alternative (depicted as Summary) to highlight the weaknesses and strengths of the processes studied. The values given in Table 4 were calculated on the basis of Formulae (1) and (2).

The summary results for each investigated treatment method indicate that BTF is the best method for removing hydrophilic compounds. In the case of hydrophobic compounds, BTs are the most convenient, with BTFs presenting very similar efficiency. The removal of inorganic compounds are characterized by the same tendency. In the case of the three methods analyzed, it is least profitable to use BS. These results are supported by the literature data $[1,12,19,20,30,73]$.

Table 4. Scores of the alternatives for each criterion.

\begin{tabular}{cccccccccc}
\hline \multirow{2}{*}{ Process } & \multicolumn{3}{c}{ Hydrophilic Compounds } & \multicolumn{3}{c}{ Hydrophobic Compounds } & \multicolumn{3}{c}{ Inorganic Compounds } \\
\cline { 2 - 10 } & BF & BTF & BS & BF & BTF & BS & BF & BTF & BS \\
\hline C1 & 0.76 & 0.93 & 0.59 & 0.90 & 0.88 & 0.44 & 0.71 & 0.67 & 0.65 \\
C2 & 0.80 & 0.58 & 0.73 & 0.80 & 0.58 & 0.73 & 0.80 & 0.58 & 0.73 \\
C3 & 0.56 & 0.88 & 0.69 & 0.56 & 0.88 & 0.69 & 0.56 & 0.88 & 0.69 \\
C4 & 0.76 & 0.80 & 0.37 & 0.76 & 0.80 & 0.37 & 0.76 & 0.80 & 0.37 \\
Summary & $\mathbf{0 . 7 4}$ & $\mathbf{0 . 7 7}$ & $\mathbf{0 . 6 0}$ & $\mathbf{0 . 7 8}$ & $\mathbf{0 . 7 6}$ & $\mathbf{0 . 5 6}$ & $\mathbf{0 . 7 2}$ & $\mathbf{0 . 7 1}$ & $\mathbf{0 . 6 1}$ \\
\hline
\end{tabular}

The distribution of the results of individual variants from various criteria is given in Table 4 . The results show that BF is a superior technique, among others compared, for the removal of hydrophobic and inorganic compounds from air. BTF proved to be the most beneficial method for removing hydrophilic compounds from air. However, it is of worth to note that very similar results are obtained for BF and BTF for all investigated types of target compounds. The most convenient process in the perspective of exploitation and operating costs is BF, while the least-economic seems to be BTF. BTF and BS presented as the most favorable processes in terms of technical aspects and possibilities of problem elimination. Processes realized in BF and BTF are also the most environmentally-friendly.

Analyzing the obtained results for the removal of hydrophobic compounds, BF is found to be the most efficient. However, BTF attains similar performance as BF in terms of the final summary result.

In terms of efficiency of $\mathrm{H} 2 \mathrm{~S}$ and ammonia removal, $\mathrm{BF}$ and BTF performance is better than BS. Both methods i.e., BF and BTF are characterized by the lowest negative influence on the environment.

Figure 4 presents the percentage distribution of the results of individual variants from various criteria, based on data from Table 4 . The analysis of Figure 4 allows to identify the adequacy of various methods for the removal of odorous compounds. 

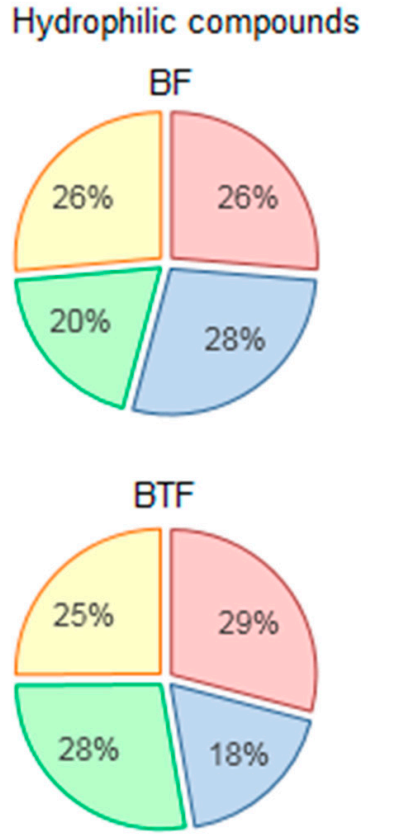

BS

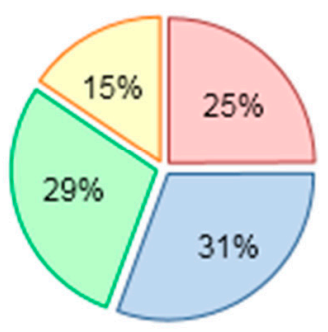

(a)
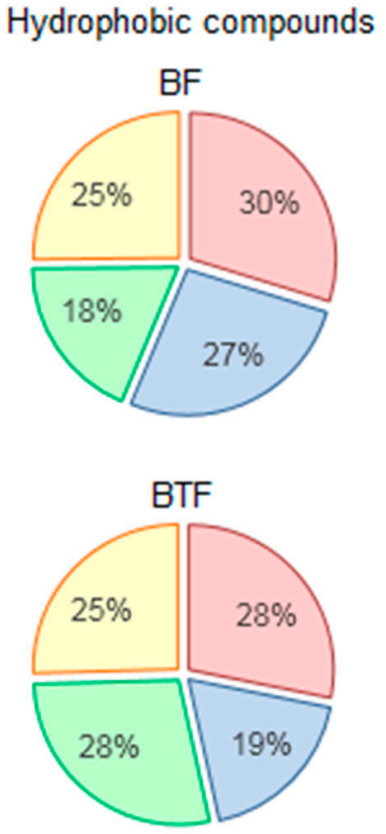

BS

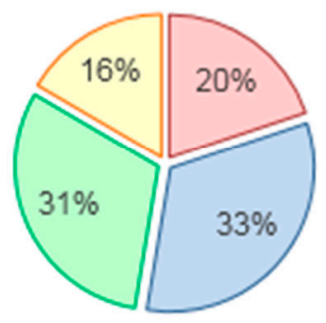

(b)
Inorganic compounds
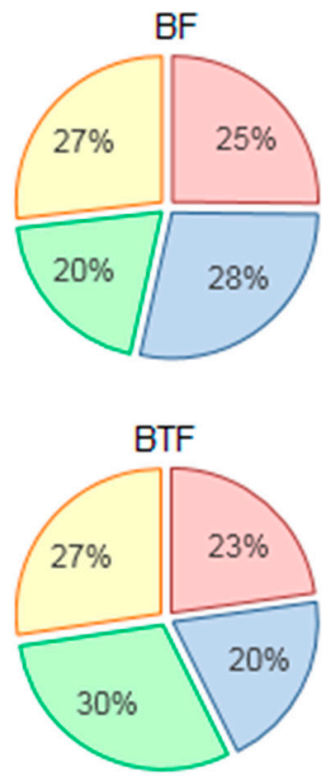

BS

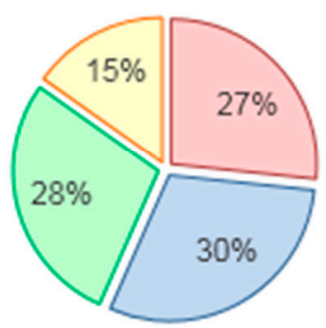

(c)

\section{$\square \quad$ Efficiency \\ ․ Costs \\ - Technical aspects and problems \\ - Environmental impact}

Figure 4. Distribution of alternative results related to different criteria for: (a) hydrophilic compounds, (b) hydrophobic compounds and (c) inorganic compounds.

The results showed that for hydrophilic compounds (Figure 4a), the highest removal efficiency is obtained using BF. BS proved to be the most beneficial due to the costs involved. Similar conclusions for BS concerned technical aspects as well as possible problems faced during the system operation. BF and BTF methods are the most environment-friendly methods. In this respect, BS differs significantly from the other two methods, due to the large production of sewage and the inability of replacing the absorbent by a secondary wastewater.

Analyzing the results for methods of hydrophobic compounds removal from air (Figure 4b), it can be stated that the greatest advantage of the BF method is high removal efficiency and environmental friendliness. The use of the BS method is reasonable when attention is paid to the costs incurred and the technical aspects together with rather low possibility of exploitation problems. In the case of BTF, the results reveal a comparable and even distribution of results for all criteria.

The results obtained for the methods in terms of the removal of inorganic compounds (Figure 4c) revealed that BTF is the optimal method when environmental issues and technical aspects with possible 
exploitation problems are considered. On the other hand, BS is outstanding in terms of efficiency and costs of treatment. Due to the fact that BF is characterized by a balanced distribution of results for all analyzed criteria, it may be regarded as a suitable method of purifying air from $\mathrm{H}_{2} \mathrm{~S}$ and $\mathrm{NH}_{3}$. Additionally, BF seems to be the best choice when none of the criteria is favored, and only optimal profitability is sought in every respect.

A similar approach of a pairwise comparison was taken up by Oliva et al. [15]. However, the comparison was focused on the advanced oxidation processes, but also included biofiltration methods. In recent years, comparative evaluation of biological methods of air treatment have been proposed by other researchers $[12,73,74]$. Similar to the results of a pairwise comparison presented in this paper, conventional biofilters seem to be the best choice. Comparing the obtained results with the outcomes of this paper it can be stated that bioscrubbers are the least-favored method of removing compounds of various types from the air.

\subsection{Result of Decision Tree for the Preliminary Selection of the Deodorization Method}

A decision tree for preliminary selection of an air deodorization method is presented in Figure 5. Table 5 presents the results of investigations used previously for the pairwise comparison procedure as well as additional data collected with the purpose of the tree development. The probability of belonging to a given group of processes is shown at the bottom of Figure 5. The presented decision tree shows, based on the input data used, that only two parameters are important when choosing the proper method i.e., the inlet concentration of a target compound and the hydrophobicity of the compound, represented by Henry's law constant.

Table 5. Data set used for the decision tree development.

\begin{tabular}{|c|c|c|c|c|c|}
\hline Process & Compound & $\begin{array}{c}\mathrm{H} \\
\left(\mathrm{mol} \cdot \mathrm{m}^{-3} \cdot \mathrm{Pa}^{-1}\right)\end{array}$ & $\begin{array}{c}\mathrm{C}_{\mathrm{in}} \\
\left(\mathrm{mg} \cdot \mathrm{m}^{-3}\right)\end{array}$ & $\begin{array}{l}\text { EBRT } \\
\text { (s) }\end{array}$ & References \\
\hline $\mathrm{BF}$ & butanol & 1.2 & 2600 & 60 & [78] \\
\hline $\mathrm{BF}$ & isopropanol & 1.3 & 8000 & 94.1 & [82] \\
\hline $\mathrm{BF}$ & ethanol & 9 & 3700 & 101 & [85] \\
\hline $\mathrm{BF}$ & methanol & 2 & 3.3 & 38 & [91] \\
\hline $\mathrm{BF}$ & hexane & 0.0061 & 10,000 & 60 & [95] \\
\hline $\mathrm{BF}$ & methane & 0.000014 & 4908 & 257 & [96] \\
\hline $\mathrm{BF}$ & ethylene & 0.000059 & 331 & 2160 & [99] \\
\hline $\mathrm{BF}$ & $\alpha$-pinene & 0.00029 & 450 & 42 & [101] \\
\hline $\mathrm{BF}$ & styrene & 0.0027 & 0.85 & 1845 & [106] \\
\hline $\mathrm{BF}$ & toluene & 0.0015 & 1.9 & 21.6 & [111] \\
\hline $\mathrm{BF}$ & ammonia & 0.59 & 350 & 17 & [115] \\
\hline $\mathrm{BF}$ & hydrogen sulfide & 0.001 & 3750 & 200 & [119] \\
\hline $\mathrm{BF}$ & hexane & 0.0061 & 700 & 30 & [121] \\
\hline $\mathrm{BF}$ & ethanol & 9 & 3700 & 150 & [85] \\
\hline $\mathrm{BF}$ & phenol & 0.025 & 1000 & 54 & [122] \\
\hline $\mathrm{BF}$ & dichloromethane & 0.0036 & 175 & 60 & [123] \\
\hline $\mathrm{BF}$ & methylamine & 0.35 & 136 & 220 & [124] \\
\hline $\mathrm{BF}$ & dimethyl sulfide & 0.0056 & 400 & 27 & [125] \\
\hline $\mathrm{BF}$ & triethylamine & 0.066 & 3000 & 60 & [126] \\
\hline $\mathrm{BF}$ & toluene & 0.0015 & 2800 & 516 & [127] \\
\hline $\mathrm{BF}$ & styrene & 0.0027 & 250 & 81 & [128] \\
\hline BS & butanol & 1.2 & 1000 & 48 & [80] \\
\hline BS & isopropanol & 1.3 & 500 & 60 & [84] \\
\hline BS & methanol & 2 & 100 & 600 & [90] \\
\hline BS & hexane & 0.0061 & 6200 & 420 & [92] \\
\hline BS & toluene & 0.0015 & 3300 & 89 & [110] \\
\hline BS & ammonia & 0.59 & 14 & 142 & [117] \\
\hline BS & hydrogen sulfide & 0.001 & 140 & 32 & [47] \\
\hline BS & trichloroethylene & 0.0011 & 300 & 931 & [129] \\
\hline BS & acetone & 0.27 & 118 & 195 & [130] \\
\hline
\end{tabular}


Table 5. Cont.

\begin{tabular}{|c|c|c|c|c|c|}
\hline Process & Compound & $\begin{array}{c}\mathrm{H} \\
\left(\mathrm{mol} \cdot \mathrm{m}^{-3} \cdot \mathrm{Pa}^{-1}\right)\end{array}$ & $\begin{array}{c}\mathrm{C}_{\mathrm{in}} \\
\left(\mathrm{mg} \cdot \mathrm{m}^{-3}\right)\end{array}$ & $\begin{array}{c}\text { EBRT } \\
(\mathbf{s})\end{array}$ & References \\
\hline BS & 1,2-dichloroethane & 0.0089 & 2400 & 300 & [131] \\
\hline BS & ethyl acetate & 0.059 & 500 & 84 & [132] \\
\hline BTF & butanol & 1.2 & 1200 & 124 & [79] \\
\hline BTF & aniline & 1.1 & 300 & 166 & [81] \\
\hline BTF & isopropanol & 1.3 & 65 & 160 & [83] \\
\hline BTF & ethanol & 9 & 470 & 66 & [86] \\
\hline BTF & methanol & 2 & 300 & 65 & [89] \\
\hline BTF & hexane & 0.0061 & 600 & 30 & [94] \\
\hline BTF & methane & 0.000014 & 500 & 240 & [97] \\
\hline BTF & ethylene & 0.000059 & 100 & 30 & {$[27,100]$} \\
\hline BTF & styrene & 0.0027 & 3300 & 120 & [105] \\
\hline BTF & toluene & 0.0015 & 1128 & 400 & [109] \\
\hline BTF & ammonia & 0.59 & 100 & 960 & [118] \\
\hline BTF & hydrogen sulfide & 0.001 & 650 & 79 & [120] \\
\hline BTF & methyl mercaptan & 0.0038 & 25 & 50 & [28] \\
\hline BTF & dimethyl sulfide & 0.0056 & 25 & 123 & [120] \\
\hline BTF & nitrobenzene & 0.64 & 300 & 24 & [133] \\
\hline BTF & aniline & 52 & 60 & 42 & [81] \\
\hline BTF & trichloroethylene & 0.0011 & 300 & 21 & [134] \\
\hline BTF & chlorobenzene & 0.0027 & 1700 & 60 & [135] \\
\hline BTF & toluene & 0.0015 & 1000 & 60 & [114] \\
\hline BTF & methyl acrylate & 0.049 & 5000 & 400 & [136] \\
\hline BTF & methyl acrylate & 0.049 & 5000 & 200 & [136] \\
\hline BTF & acetone & 0.27 & 8000 & 137 & [137] \\
\hline BTF & styrene & 0.0027 & 1000 & 90 & [105] \\
\hline BTF & formaldehyde & 3.2 & 100 & 80 & [138] \\
\hline BTF & isopropanol & 1.3 & 1000 & 140 & [139] \\
\hline
\end{tabular}

The decision tree learning algorithm is a non-arbitrary algorithm. A tree was "learned" by splitting the training set into subsets based on an attribute value test. This process was repeated on each derived subset in a recursive manner called recursive partitioning. The recursion is completed when the subset at a node has all the same values of the target variable, or when splitting no longer adds value to the predictions.

In the decision tree model development, only process performance was included, while cost analysis was excluded. Considering such an approach, for high inlet concentrations (higher than $2500 \mathrm{mg} \cdot \mathrm{m}^{-3}$ ), the best treatment option is to use the conventional biofilter. Traditional biofilters based on natural packing materials, for both hydrophilic and hydrophobic compounds, tend to be applied when relatively high inlet concentrations are used $[78,82,93,95,96,119]$. The use of large EBRT values is necessary for high inlet concentrations, which consequently significantly increases the dimensions of the apparatus. Organic packing materials are cheaper than synthetic ones. The use of a trickling or absorption liquid (BTF and BS) at high concentrations generates the necessity of its frequent replacement (hydrophobic compounds very quickly achieve the saturation state of the liquid), the use of surfactants or increase in the dimensions of the apparatus. The results of applied algorithms show that for the inlet concentrations lower than $2500 \mathrm{mg} \cdot \mathrm{m}^{-3}$ and for hydrophilic compounds, biotrickling filtration seems to be the best treatment method. Similar results are obtained for hydrophobic compounds for the inlet concentration range between 475 and $2500 \mathrm{mg} \cdot \mathrm{m}^{-3}$. If concentration is lower than $475 \mathrm{mg} \cdot \mathrm{m}^{-3}$, the better choice will be the application of a conventional biofilter. Bioscrubbers may be used for compounds characterized by Henry's law constant between 0.0075 and $0.62 \mathrm{~mol} \cdot \mathrm{m}^{-3} \cdot \mathrm{Pa}^{-1}$ and for inlet concentrations lower than $2500 \mathrm{mg} \cdot \mathrm{m}^{-3}$. In this group of compounds, the use of a conventional biofilter should also be considered (due to the low differences in probability of belonging to a given group: $50 \%$ and $38 \%$ for the bioscrubber and conventional biofilter, respectively). 


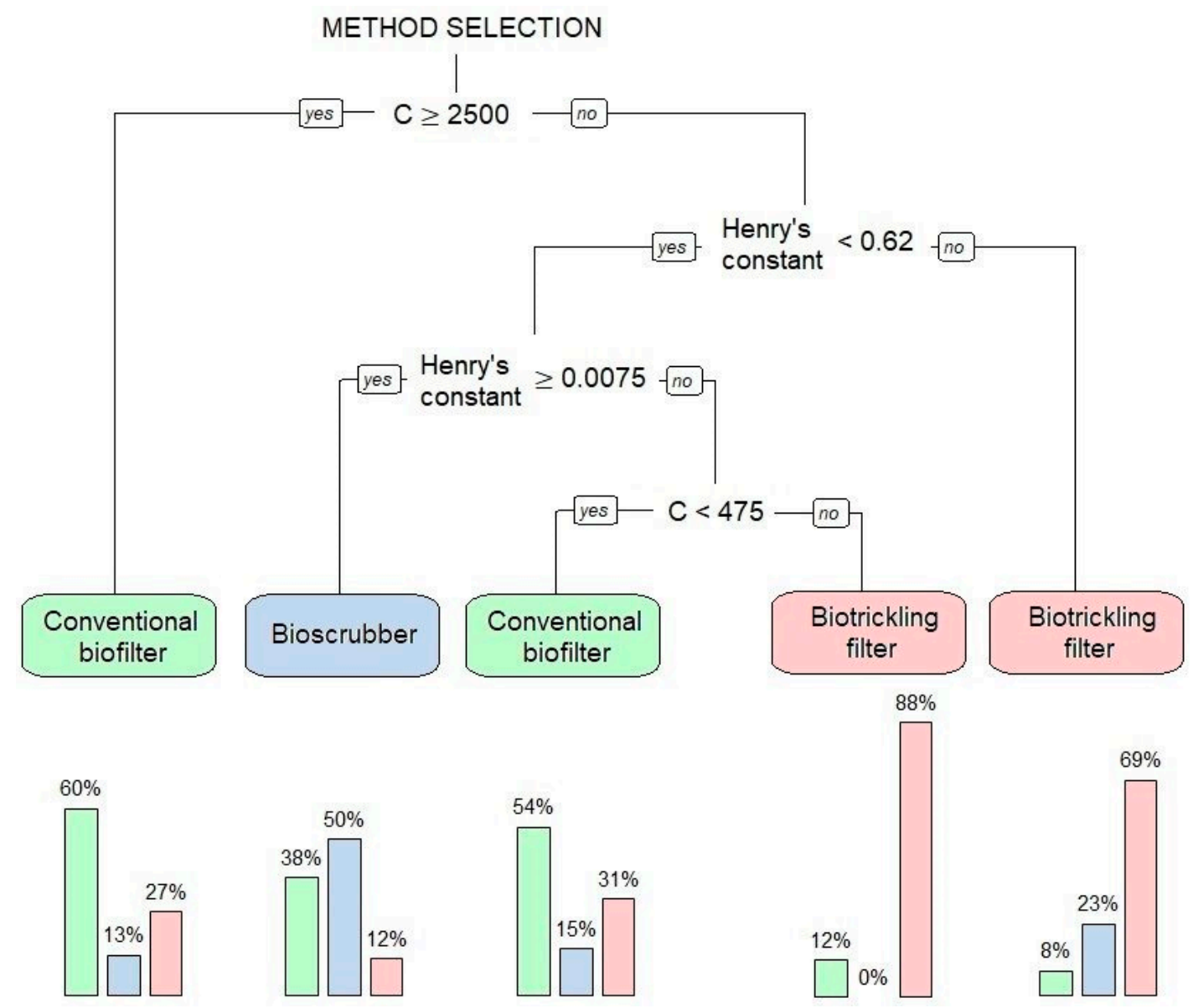

Figure 5. Developed decision tree for the selection of the most suitable biological treatment method $\left(\mathrm{C}\right.$-inlet concentration, $\mathrm{mg} \cdot \mathrm{m}^{-3}$; Henry's constant, $\left.\mathrm{mol} \cdot \mathrm{m}^{-3} \cdot \mathrm{Pa}^{-1}\right)$.

\subsection{Practical Applications and Future Research Perspectives}

The presented comparative analysis together with a proposed decision tree model seem to be useful when selecting a treatment procedure for air polluted with odorous compounds. Current development of the legislation regarding the odorous quality of air implies the increased interest in sustainable and efficient deodorization methods, thus the use of biological methods with applications in industrial, agricultural as well as indoor air treatment applications will in particular be increasing in the nearby future. Additionally, currently observed development of these methods, especially when biotrickling filtration is considered, suggests highly probable possibility of eliminating most of the related problems e.g., the effective removal of hydrophobic air pollutants or efficient long-term operation of biological systems. The results of comparative assessment of investigated deodorization methods presented in this paper may, therefore, aid the decision-making process when considering the most efficient biological method of air deodorization.

This paper presents a prototype of a decision model, which after expansion, based on a larger set of input data, will allow for a quick selection of the appropriate method of purification of air polluted with specific compounds. Such an extension of the procedure proposed in this paper is planned by the authors. The future model will take into account the inlet concentrations, geometry as well as the dimensions of apparatus and all important process parameters, including the gas flow rate but also the packed bed material as well as microbial species, especially those selected for the efficient removal of specific compounds from air. In this perspective, the authors believe that a future model will aid and simplify the selection of the treatment method, especially for industrial applications (e.g., pulp and paper, chemical of pharmaceutical) providing that all required input data are available. 


\section{Conclusions}

The results of the comparative evaluation indicate that conventional biofilters and biotrickling filters exhibit similar and good performance of treatment of hydrophobic compounds. Biotrickling filters are superior in terms of the removal of hydrophilic compounds while bioscrubbers present moderate or low performance when compared to BF and BTF. The decision rules obtained from the decision tree method suggest that the most important parameters in the method selection are: inlet concentration and Henry's constant. Based on the literature data presented in this study, the decision tree output suggests using conventional biofilters for the treatment of relatively highly concentrated streams (concentration above $2500 \mathrm{mg} \cdot \mathrm{m}^{-3}$ ). For streams with concentrations of odorous compounds lower than depicted, biotrickling filtration is a more suitable method than biofiltration or bioscrubbing. This manuscript reveals the first iteration of the problem related to the selection of the treatment method for hydrophilic and hydrophobic odorous compounds using a proposed decision algorithm. Further expansion of this algorithm is planned in the future and it will be based on more complex input data, including a packing material type or microbial species with the perspective of facilitating the method selection process.

Author Contributions: M.G., P.R., B.S. and J.G. wrote a paper. M.G. revised the literature data, prepared a method of comparison and performed the calculations. P.R. revised the literature for the introduction and discussed the results. B.S. developed a decision tree model. J.G. supervised the preparation of the manuscript, consulted with discussions, and prepared the final conclusions.

Funding: This research received no external funding.

Acknowledgments: The authors are grateful for the support by the project "INTERPHD2" No. POWR.03.02.00-IP.08-00-DOC/16.

Conflicts of Interest: The authors declare no conflict of interest.

\section{References}

1. Barbusinski, K.; Kalemba, K.; Kasperczyk, D.; Urbaniec, K.; Kozik, V. Biological methods for odor treatment-A review. J. Clean. Prod. 2017, 152, 223-241. [CrossRef]

2. Qian, H.; Cheng, Y.; Yang, C.; Wu, S.; Zeng, G.; Xi, J. Performance and biofilm characteristics of biotrickling filters for ethylbenzene removal in the presence of saponins. Environ. Sci. Pollut. Res. 2018, 25, 30021-30030. [CrossRef]

3. Wu, H.; Yan, H.; Quan, Y.; Zhao, H.; Jiang, N.; Yin, C. Recent progress and perspectives in biotrickling filters for VOCs and odorous gases treatment. J. Environ. Manag. 2018, 222, 409-419. [CrossRef] [PubMed]

4. Brancher, M.; Griffiths, K.D.; Franco, D.; de Melo Lisboa, H. A review of odour impact criteria in selected countries around the world. Chemosphere 2017, 168, 1531-1570. [CrossRef]

5. Rybarczyk, P.; Szulczyński, B.; Gebicki, J.; Hupka, J. Treatment of malodorous air in biotrickling filters: A review. Biochem. Eng. J. 2019, 141, 146-162. [CrossRef]

6. Darlington, A.B.; Dat, J.F.; Dixon, M.A. The Biofiltration of Indoor Air: Air Flux and Temperature Influences the Removal of Toluene, Ethylbenzene, and Xylene. Environ. Sci. Technol. 2001, 35, 240-246. [CrossRef] [PubMed]

7. Darlington, A.; Chan, M.; Malloch, D.; Pilger, C.; Dixon, M.A. The Biofiltration of Indoor Air: Implications for Air Quality. Indoor Air 2000, 10, 39-46. [CrossRef]

8. Torpy, F.; Clements, N.; Pollinger, M.; Dengel, A.; Mulvihill, I.; He, C.; Irga, P. Testing the single-pass VOC removal efficiency of an active green wall using methyl ethyl ketone (MEK). Air Qual. Atmos. Health 2018, 11, 163-170. [CrossRef]

9. Ondarts, M.; Hort, C.; Platel, V.; Sochard, S. Indoor Air Purification by Compost Packed Biofilter. Int. J. Chem. React. Eng. 2010, 8. [CrossRef]

10. Pratt, C.; Walcroft, A.S.; Tate, K.R.; Ross, D.J.; Roy, R.; Reid, M.H.; Veiga, P.W. Biofiltration of methane emissions from a dairy farm effluent pond. Agric. Ecosyst. Environ. 2012, 152, 33-39. [CrossRef]

11. Dumont, E.; Hamon, L.; Lagadec, S.; Landrain, P.; Landrain, B.; Andrès, Y. $\mathrm{NH}_{3}$ biofiltration of piggery air. J. Environ. Manag. 2014, 140, 26-32. [CrossRef] 
12. Miller, U.; Sówka, I.; Grzelka, A.; Pawnuk, M. Application of biological deodorization methods in the aspect of sustainable development. In Proceedings of the SHS Web Conference, Gdańsk-Nynäshamn, Poland, 18-20 September 2018; Volume 57.

13. Szulczyński, B.; Wasilewski, T.; Wojnowski, W.; Majchrzak, T.; Dymerski, T.; Namieśnik, J.; Gębicki, J. Different Ways to Apply a Measurement Instrument of E-Nose Type to Evaluate Ambient Air Quality with Respect to Odour Nuisance in a Vicinity of Municipal Processing Plants. Sensors 2017, 17, 2671. [CrossRef] [PubMed]

14. Khan, F.I.; Ghoshal, A.K. Removal of Volatile Organic Compounds from polluted air. J. Loss Prev. Process Ind. 2000, 13, 527-545. [CrossRef]

15. Oliva, G.; Zarra, T.; Naddeo, V.; Munoz, R.; Lebrero, R.; Angeles, R.; Belgiorno, V.; Ángeles, R.; Belgiorno, V. Comparative Analysis of AOPs and Biological Processes for the Control of VOCs Industrial Emissions. In Proceedings of the Chemical Engineering Transactions, Milan, Italy, 9-12 September 2018; Volume 68, pp. 451-456.

16. Schiavon, M.; Ragazzi, M.; Rada, E.C.; Torretta, V. Air pollution control through biotrickling filters: A review considering operational aspects and expected performance. Crit. Rev. Biotechnol. 2016, 36, 1143-1155. [CrossRef] [PubMed]

17. Yu, J.; Liu, W.; Cheng, Z.; Jiang, Y.; Cai, W.; Chen, J. Dichloromethane removal and microbial variations in a combination of UV pretreatment and biotrickling filtration. J. Hazard. Mater. 2014, 268, 14-22.

18. Abraham, S.; Joslyn, S.; Suffet, I.H. (Mel) Treatment of odor by a seashell biofilter at a wastewater treatment plant. J. Air Waste Manag. Assoc. 2015, 65, 1217-1228. [CrossRef] [PubMed]

19. Mudliar, S.; Giri, B.; Padoley, K.; Satpute, D.; Dixit, R.; Bhatt, P.; Pandey, R.; Juwarkar, A.; Vaidya, A. Bioreactors for treatment of VOCs and odours-A review. J. Environ. Manag. 2010, 91, 1039-1054. [CrossRef]

20. Vikrant, K.; Kim, K.H.; Szulejko, J.E.; Pandey, S.K.; Singh, R.S.; Giri, B.S.; Brown, R.J.C.; Lee, S.H. Bio-filters for the treatment of VOCs and odors-A review. Asian J. Atmos. Environ. 2017, 11, 139-152. [CrossRef]

21. Szulczyński, B.; Gębicki, J.; Namieśnik, J. Monitoring and efficiency assessment of biofilter air deodorization using electronic nose prototype. Chem. Pap. 2018, 72, 527-532. [CrossRef]

22. McNevin, D.; Barford, J. Biofiltration as an odour abatement strategy. Biochem. Eng. J. 2000, 5, $231-242$. [CrossRef]

23. Chmiel, K.; Jastrzębski, A.B.; Palica, M. Biofiltracja lotnych związków organicznych. Przem. Chem. 2005, 6, 442-445.

24. Ferdowsi, M.; Avalos Ramirez, A.; Jones, J.P.; Heitz, M. Elimination of mass transfer and kinetic limited organic pollutants in biofilters: A review. Int. Biodeterior. Biodegrad. 2017, 119, 336-348. [CrossRef]

25. Szulczyński, B.; Rybarczyk, P.; Gębicki, J. Monitoring of n-butanol vapors biofiltration process using an electronic nose combined with calibration models. Monatshefte für Chem. Chem. Mon. 2018, 149, 1693-1699. [CrossRef] [PubMed]

26. Viotti, P.; Schiavon, M.; Gavasci, R.; Capodaglio, A.G. Removal of benzene and toluene from a refinery waste air stream by water sorption and biotrickling filtration. Interdiscip. J. Appl. Sci. 2015, 10, 720-727.

27. Zdeb, M.; Lebiocka, M. Microbial removal of selected volatile organic compounds from the model landfill gas. Ecol. Chem. Eng. S 2016, 23, 215-228. [CrossRef]

28. Lebrero, R.; Rodríguez, E.; Estrada, J.M.; García-Encina, P.A.; Muñoz, R. Odor abatement in biotrickling filters: Effect of the EBRT on methyl mercaptan and hydrophobic VOCs removal. Bioresour. Technol. 2012, 109, 38-45. [CrossRef]

29. Yang, C.; Qian, H.; Li, X.; Cheng, Y.; He, H.; Zeng, G.; Xi, J. Simultaneous Removal of Multicomponent VOCs in Biofilters. Trends Biotechnol. 2018, 36, 673-685. [CrossRef]

30. Cheng, Y.; He, H.; Yang, C.; Zeng, G.; Li, X.; Chen, H.; Yu, G. Challenges and solutions for biofiltration of hydrophobic volatile organic compounds. Biotechnol. Adv. 2016, 34, 1091-1102. [CrossRef] [PubMed]

31. Iranpour, R.; Cox, H.H.J.; Deshusses, M.A.; Schroeder, E.D. Literature review of air pollution control biofilters and biotrickling filters for odor and volatile organic compound removal. Environ. Prog. 2005, 24, 254-267. [CrossRef]

32. Lu, C.; Lin, M.-R.; Chu, C. Temperature Effects of Trickle-Bed Biofilter for Treating BTEX Vapors. J. Environ. Eng. 1999, 125, 775-779. [CrossRef] 
33. Mirpuri, R.; Jones, W.; Bryers, J.D. Toluene degradation kinetics for planktonic and biofilm-grown cells ofPseudomonas putida 54G. Biotechnol. Bioeng. 1997, 53, 535-546. [CrossRef]

34. Vaiškūnaitè, R.; Zagorskis, A. Modelling of a biofiltration process of volatile organic compound mixtures in a biofilter. Biotechnol. Biotechnol. Equip. 2016, 30, 1217-1222. [CrossRef]

35. Gaszczak, A.; Bartelmus, G.; Burghardt, A.; Rotkegel, A.; Sarzyński, R. Experiments and modelling of a biotrickling filter (BTF) for removal of styrene from airstreams. J. Chem. Technol. Biotechnol. 2018, 93, 2659-2670. [CrossRef]

36. Ahmed, W.; Shareefdeen, Z.M.; Jabbar, N.A. Dynamic modeling and analysis of biotrickling filters in continuous operation for H2S removal. Clean Technol. Environ. Policy 2014, 16, 1757-1765. [CrossRef]

37. Almenglo, F.; Ramírez, M.; Gómez, J.M.; Cantero, D.; Gamisans, X.; Dorado, A.D. Modeling and control strategies for anoxic biotrickling filtration in biogas purification. J. Chem. Technol. Biotechnol. 2016, 91, 1782-1793. [CrossRef]

38. Vergara-Fernández, A.; Revah, S.; Moreno-Casas, P.; Scott, F. Biofiltration of volatile organic compounds using fungi and its conceptual and mathematical modeling. Biotechnol. Adv. 2018, 36, 1079-1093. [CrossRef]

39. Yoon, H.; Song, M.J.; Kim, D.D.; Sabba, F.; Yoon, S. A Serial Biofiltration System for Effective Removal of Low-Concentration Nitrous Oxide in Oxic Gas Streams: Mathematical Modeling of Reactor Performance and Experimental Validation. Environ. Sci. Technol. 2019, 53, 2063-2074. [CrossRef]

40. Toledo-Cervantes, A.; Lebrero, R.; Cavinato, C.; Muñoz, R. Biogas upgrading using algal-bacterial processes. Microalgae Based Biofuels Bioprod. 2017, 283-304. [CrossRef]

41. Han, M.-F.; Wang, C.; Liu, H. Comparison of physical technologies for biomass control in biofilters treating gaseous toluene. J. Air Waste Manag. Assoc. 2018, 68, 1118-1125. [CrossRef]

42. López de León, L.R.; Deaton, K.E.; Deshusses, M.A. Miniaturized Biotrickling Filters and Capillary Microbioreactors for Process Intensification of VOC Treatment with Intended Application to Indoor Air. Environ. Sci. Technol. 2019, 53, 1518-1526. [CrossRef]

43. Aguirre, A.; Bernal, P.; Maureira, D.; Ramos, N.; Vásquez, J.; Urrutia, H.; Gentina, J.C.; Aroca, G. Biofiltration of trimethylamine in biotrickling filter inoculated with Aminobacter aminovorans. Electron. J. Biotechnol. 2018, 33, 63-67. [CrossRef]

44. San-Valero, P.; Gabaldón, C.; Álvarez-Hornos, F.J.; Izquierdo, M.; Martínez-Soria, V. Removal of acetone from air emissions by biotrickling filters: Providing solutions from laboratory to full-scale. J. Environ. Sci. Health Part A 2018, 1-8. [CrossRef]

45. Dumont, É. Impact of the treatment of $\mathrm{NH}_{3}$ emissions from pig farms on greenhouse gas emissions. Quantitative assessment from the literature data. New Biotechnol. 2018, 46, 31-37. [CrossRef] [PubMed]

46. Wysocka, I.; Gębicki, J.; Namieśnik, J. Technologies for deodorization of malodorous gases. Environ. Sci. Pollut. Res. 2019, 1-26. [CrossRef] [PubMed]

47. Potivichayanon, S.; Pokethitiyook, P.; Kruatrachue, M. Hydrogen sulfide removal by a novel fixed-film bioscrubber system. Process Biochem. 2006, 41, 708-715. [CrossRef]

48. Barbusiński, K.; Kalemba, K. Use of biological methods for removal of H2S from biogas in wastewater treatment plants-A review. Archit. Civ. Eng. Environ. 2016, 9, 103-112. [CrossRef]

49. Malakar, S.; Saha, P.D.; Baskaran, D.; Rajamanickam, R. Comparative study of biofiltration process for treatment of VOCs emission from petroleum refinery wastewater-A review. Environ. Technol. Innov. 2017, 8, 441-461. [CrossRef]

50. Taghipour, H.; Shahmansoury, M.R.; Bina, B.; Movahdian, H. Comparison of the biological $\mathrm{NH}_{3}$ removal characteristics of a three stage biofilter with a one stage biofilter. Int. J. Environ. Sci. Technol. 2006, 3, 417-424. [CrossRef]

51. Gao, L.; Keener, T.C.; Zhuang, L.; Siddiqui, K.F. A technical and economic comparison of biofiltration and wet chemical oxidation (scrubbing) for odor control at wastewater treatment plants. Environ. Eng. Policy 2001, 2, 203-212. [CrossRef]

52. Saaty, T.L. Relative Measurement and Its Generalization in Decision Making Why Pairwise Comparisons are Central in Mathematics for the Measurement of Intangible Factors The Analytic Hierarchy/Network Process. RACSAM-Revista de la Real Academia de Ciencias Exactas Fisicas y Naturales Serie A Matematicas 2008, 102, 251-318. [CrossRef] 
53. Brunelli, M.; Canal, L.; Fedrizzi, M. Inconsistency indices for pairwise comparison matrices: A numerical study. Ann. Oper. Res. 2013, 211, 493-509. [CrossRef]

54. Chang, D.Y. Applications of the extent analysis method on fuzzy AHP. Eur. J. Oper. Res. 1996, 95, 649-655. [CrossRef]

55. Kabir, G.; Sadiq, R.; Tesfamariam, S. A review of multi-criteria decision-making methods for infrastructure management. Struct. Infrastruct. Eng. 2014, 10, 1176-1210. [CrossRef]

56. Soltani, A.; Sadiq, R.; Hewage, K. Selecting sustainable waste-to-energy technologies for municipal solid waste treatment: A game theory approach for group decision-making. J. Clean. Prod. 2016, 113, 388-399. [CrossRef]

57. Palmer, E.J.; Devitt, P.G.; De Young, N.J.; Morris, D. Assessment of an electronic voting system within the tutorial setting: A randomised controlled trial [ISRCTN54535861]. BMC Med. Educ. 2005, 5, 24. [CrossRef]

58. Laukkanen, S.; Kangas, A.; Kangas, J. Applying voting theory in natural resource management: A case of multiple-criteria group decision support. J. Environ. Manag. 2002, 64, 127-137. [CrossRef]

59. Nurmi, H. Voting Procedures: A Summary Analysis. Br. J. Political Sci. 1983, 13, 181-208. [CrossRef]

60. Oishi, S.; Hahn, J.; Schimmack, U.; Radhakrishan, P.; Dzokoto, V.; Ahadi, S. The measurement of values across cultures: A pairwise comparison approach. J. Res. Pers. 2005, 39, 299-305. [CrossRef]

61. Martignon, L.; Hoffrage, U. Fast, frugal, and fit: Simple heuristics for paired comparison. Theory Decis. 2002, 52, 29-71. [CrossRef]

62. Chan, F.T.S.; Jiang, B.; Tang, N.K.H. The development of intelligent decision support tools to aid the design of flexible manufacturing systems. Int. J. Prod. Econ. 2000, 65, 73-84. [CrossRef]

63. Kok, M.; Lootsma, F.A. Pairwise-comparison methods in multiple objective programming, with applications in a long-term energy-planning model. Eur. J. Oper. Res. 1985, 22, 44-55. [CrossRef]

64. Kaya, T.; Kahraman, C. Multicriteria decision making in energy planning using a modified fuzzy TOPSIS methodology. Expert Syst. Appl. 2011, 38, 6577-6585. [CrossRef]

65. Colombo, J.; Richman, W.A.; Shaddy, D.J.; Follmer Greenhoot, A.; Maikranz, J.M. Heart Rate-Defined Phases of Attention, Look Duration, and Infant Performance in the Paired-Comparison Paradigm. Child Dev. 2001, 72, 1605-1616. [CrossRef]

66. Quinlan, J.R. Induction of decision trees. Mach. Learn. 1986, 1, 81-106. [CrossRef]

67. Breiman, L.; Friedman, J.H.; Olshen, R.A.; Stone, C.J. Classification and Regression Trees; Chapman \& Hall/CRC: New York, NY, USA, 1984.

68. Hastie, T.; Tibshirani, R.; Friedman, J. The Element of Statistical Learning; Springer: New York, NY, USA, 2001.

69. Chang, L.-Y.; Wang, H.-W. Analysis of traffic injury severity: An application of non-parametric classification tree techniques. Accid. Anal. Prev. 2006, 38, 1019-1027. [CrossRef] [PubMed]

70. RStudio Team. RStudio Integrated Development Environment for R. Available online: https: / / www.rstudio. com/ (accessed on 25 February 2019).

71. Therneau, T.; Atkinson, B. Rpart: Recursive Partitioning and Regression Trees; Comprehensive R Archive Network (CRAN): Rochester, MN, USA, 2018.

72. Joanna, K.; Mazur-Chrzanowska, B.; Wyszyński, B. Odory; Wydawnictwo Naukowe PWN: Warszawa, Poland, 2012.

73. Estrada, J.M.; Bart Kraakman, N.J.R.; Muñoz, R.; Lebrero, R. A Comparative Analysis of Odour Treatment Technologies in Wastewater Treatment Plants. Environ. Sci. Technol. 2011, 45, 1100-1106. [CrossRef] [PubMed]

74. Estrada, J.M.; Kraakman, B.; Lebrero, R.; Muñoz, R. A sensitivity analysis of process design parameters, commodity prices and robustness on the economics of odour abatement technologies. Biotechnol. Adv. 2012, 30, 1354-1363. [CrossRef] [PubMed]

75. Webb, D.S. Best Design Practices for Odour Management for Organics Processing Facilities. In Proceedings of the A\&WMA Waste Conference 2014, Long Beach, CA, USA, 24-27 June 2014.

76. Rybarczyk, P.; Szulczyński, B.; Gębicki, J. Investigations on the Removal of Hydrophobic Odorous Volatile Organic Compounds by Biotrickling Filtration Monitored with Electronic Nose. Chem. Eng. Trans. 2018, 68. [CrossRef]

77. Sander, R. Compilation of Henry's law constants (version 4.0) for water as solvent. Atmos. Chem. Phys. 2015, 15, 4399-4981. [CrossRef] 
78. Eshraghi, M.; Parnian, P.; Zamir, S.M.; Halladj, R. Biofiltration of n-butanol vapor at different operating temperatures: Experimental study and mathematical modeling. Int. Biodeterior. Biodegrad. 2017, 119, 361-367. [CrossRef]

79. Schmidt, T.; Anderson, W.A.; Schmidt, T.; Anderson, W.A. Biotrickling Filtration of Air Contaminated with 1-Butanol. Environments 2017, 4, 57. [CrossRef]

80. Wübker, S.M.; Friedrich, C.G. Reduction of biomass in a bioscrubber for waste gas treatment by limited supply of phosphate and potassium ions. Appl. Microbiol. Biotechnol. 1996, 46, 475-480. [CrossRef]

81. Li, G.; Wan, S.; An, T. Efficient bio-deodorization of aniline vapor in a biotrickling filter: Metabolic mineralization and bacterial community analysis. Chemosphere 2012, 87, 253-258. [CrossRef] [PubMed]

82. Krailas, S.; Tongta, S.; Meeyoo, V. Macrokinetic determination of isopropanol removal using a downward flow biofilter. Songklanakarin J. Sci. Technol. 2004, 26, 55-64.

83. San-Valero, P.; Penya-Roja, J.M.; Sempere, F.; Gabaldón, C. Biotrickling filtration of isopropanol under intermittent loading conditions. Bioprocess Biosyst. Eng. 2013, 36, 975-984. [CrossRef] [PubMed]

84. Whaley, M.B.; Monroig, P.; Villarubia, E. Allergan-isopropyl alcohol emissions removal using a unique biological system. Environ. Prog. 1998, 17, 256-260. [CrossRef]

85. Auria, R.; Aycaguer, A.-C.; Devinny, J.S. Influence of Water Content on Degradation Rates for Ethanol in Biofiltration. J. Air Waste Manag. Assoc. 1998, 48, 65-70. [CrossRef]

86. Morotti, K.; Ramirez, A.A.; Jones, J.P.; Heitz, M. Analysis and comparison of biotreatment of air polluted with ethanol using biofiltration and biotrickling filtration. Environ. Technol. 2011, 32, 1967-1973. [CrossRef]

87. Singh, A.; Shareefdeen, Z.; Ward, O.P. Bioscrubber Technology. In Biotechnology for Odor and Air Pollution Control; Springer: Berlin/Heidelberg, Germany, 2005; pp. 169-193.

88. Allen, L.; Ellis, S. Laboratory Evaluation of Trickling Biofiltration for Treatment of Kraft Mill Noncombustion Air Emissions. In Proceedings of the TAPPI 2000 Environmental Confrence Processdins, Denver, CO, USA, 21-24 May 2000; pp. 293-309.

89. Avalos Ramirez, A.; Peter Jones, J.; Heitz, M. Control of methanol vapours in a biotrickling filter: Performance analysis and experimental determination of partition coefficient. Bioresour. Technol. 2009, 100, 1573-1581. [CrossRef]

90. DeHollander, G.R.; Overcamp, T.J.; Grady, C., Jr.; Grady, C. Performance of a Suspended-Growth Bioscrubber for the Control of Methanol. J. Air Waste Manag. Assoc. 1998, 48, 872-876. [CrossRef]

91. Prekumar, R.; Krishnamohan, N. Removal of Methanol from Waste Gas Using Biofiltration. J. Appl. Sci. Res. 2010, 6, 1898-1907.

92. Lalanne, F.; Malhautier, L.; Roux, J.-C.; Fanlo, J.-L. Absorption of a mixture of volatile organic compounds (VOCs) in aqueous solutions of soluble cutting oil. Bioresour. Technol. 2008, 99, 1699-1707. [CrossRef] [PubMed]

93. Arriaga, S.; Revah, S. Removal of n-hexane by Fusarium solani with a gas-phase biofilter. J. Ind. Microbiol. Biotechnol. 2005, 32, 548-553. [CrossRef] [PubMed]

94. Tu, Y.; Yang, C.; Cheng, Y.; Zeng, G.; Lu, L.; Wang, L. Effect of saponins on n-hexane removal in biotrickling filters. Bioresour. Technol. 2015, 175, 231-238. [CrossRef] [PubMed]

95. Arriaga, S.; Revah, S. Improving hexane removal by enhancing fungal development in a microbial consortium biofilter. Biotechnol. Bioeng. 2005, 90, 107-115. [CrossRef]

96. Nikiema, J.; Bibeau, L.; Lavoie, J.; Brzezinski, R.; Vigneux, J.; Heitz, M. Biofiltration of methane: An experimental study. Chem. Eng. J. 2005, 113, 111-117. [CrossRef]

97. Lebrero, R.; Hernández, L.; Pérez, R.; Estrada, J.M.; Muñoz, R. Two-liquid phase partitioning biotrickling filters for methane abatement: Exploring the potential of hydrophobic methanotrophs. J. Environ. Manag. 2015, 151, 124-131. [CrossRef] [PubMed]

98. Liu, F.; Fiencke, C.; Guo, J.; Rieth, R.; Dong, R.; Pfeiffer, E.-M. Performance evaluation and optimization of field-scale bioscrubbers for intensive pig house exhaust air treatment in northern Germany. Sci. Total Environ. 2017, 579, 694-701. [CrossRef]

99. Kim, J.-O. Degradation of benzene and ethylene in biofilters. Process Biochem. 2003, 39, 447-453. [CrossRef]

100. Barzgar, S.; Hettiaratchi, J.P.; Pearse, L.; Kumar, S. Inhibitory effects of acidic $\mathrm{pH}$ and confounding effects of moisture content on methane biofiltration. Bioresour. Technol. 2017, 245, 633-640. [CrossRef]

101. van Groenestijn, J.W.; Liu, J.X. Removal of alpha-pinene from gases using biofilters containing fungi. Atmos. Environ. 2002, 36, 5501-5508. [CrossRef] 
102. Montes, M.; Daugulis, A.J.; Veiga, M.C.; Kennes, C. Removal of $\alpha$-pinene from waste gases in biotrickling filters with the addition of silicone oil or polymers. J. Biotechnol. 2010, 150, 221. [CrossRef]

103. Miller, M.J.; Allen, D.G. Modelling transport and degradation of hydrophobic pollutants in biofilter biofilms. Chem. Eng. J. 2005, 113, 197-204. [CrossRef]

104. Kraakman, N.J.R.; van Groenestijn, J.W.; Koers, B.; Heslinga, D.C. Mededelingen Faculteit Lanbouwkundige en Toegepaste Biologische Wetenschapper. Univ. Gent 1997, 62, 1535-1541.

105. Zamir, S.M.; Babatabar, S.; Shojaosadati, S.A. Styrene vapor biodegradation in single- and two-liquid phase biotrickling filters using Ralstonia eutropha. Chem. Eng. J. 2015, 268, 21-27. [CrossRef]

106. Ramay, M.J.; Porter, R.; Johnson, S.; Dasgupta, A.; Robbins, J. Pilot biofilter demonstration for styrene, MEK (methyl ethyl ketone), and methylene chloride emissions. In Proceedings of the 4th International In Situ On-Site Bioremediation Symposium, New Orleans, LA, USA, 28 April-1 May 1997; Volume 5, pp. 225-230.

107. San-Valero, P.; Dorado, A.D.; Martínez-Soria, V.; Gabaldón, C. Biotrickling filter modeling for styrene abatement. Part 1: Model development, calibration and validation on an industrial scale. Chemosphere 2018, 191, 1066-1074. [CrossRef]

108. Rene, E.R.; Murthy, D.V.S.; Swaminathan, T. Performance evaluation of a compost biofilter treating toluene vapours. Process Biochem. 2005, 40, 2771-2779. [CrossRef]

109. Kim, D.; Cai, Z.; Sorial, G.A. Behavior of trickle-bed air biofilter for toluene removal: Effect of non-use periods. Environ. Prog. 2005, 24, 155-161. [CrossRef]

110. Díaz, L.F.; Muñoz, R.; Bordel, S.; Villaverde, S. Toluene biodegradation by Pseudomonas putida F1: Targeting culture stability in long-term operation. Biodegradation 2008, 19, 197-208. [CrossRef] [PubMed]

111. Delhoménie, M.-C.; Bibeau, L.; Gendron, J.; Brzezinski, R.; Heitz, M. A study of clogging in a biofilter treating toluene vapors. Chem. Eng. J. 2003, 94, 211-222. [CrossRef]

112. Cox, H.H.J.; Deshusses, M.A. Co-treatment of H2S and toluene in a biotrickling filter. Chem. Eng. J. 2002, 87, 101-110. [CrossRef]

113. García-Peña, E.I.; Hernández, S.; Favela-Torres, E.; Auria, R.; Revah, S. Toluene biofiltration by the fungus Scedosporium apiospermum TB1. Biotechnol. Bioeng. 2001, 76, 61-69. [CrossRef]

114. Cox, H.H.J.; Deshusses, M.A. Biomass control in waste air biotrickling filters by protozoan predation. Biotechnol. Bioeng. 1999, 62, 216-224. [CrossRef]

115. Liang, Y.; Quan, X.; Chen, J.; Chung, J.S.; Sung, J.Y.; Chen, S.; Xue, D.; Zhao, Y. Long-term results of ammonia removal and transformation by biofiltration. J. Hazard. Mater. 2000, 80, 259-269. [CrossRef]

116. Melse, R.W.; Ploegaert, J.P.M.; Ogink, N.W.M. Biotrickling filter for the treatment of exhaust air from a pig rearing building: Ammonia removal performance and its fluctuations. Biosyst. Eng. 2012, 113, 242-252. [CrossRef]

117. Nisola, G.M.; Cho, E.; Orata, J.D.; Redillas, M.C.F.R.; Farnazo, D.M.C.; Tuuguu, E.; Chung, W.J. NH 3 gas absorption and bio-oxidation in a single bioscrubber system. Process Biochem. 2009, 44, 161-167. [CrossRef]

118. Jun, Y.; $\mathrm{Xu}, \mathrm{W}$. Ammonia biofiltration and community analysis of ammonia-oxidizing bacteria in biofilters. Bioresour. Technol. 2009, 100, 3869-3876. [CrossRef] [PubMed]

119. Yang, Y.; Allen, E.R. Biofiltration Control of Hydrogen Sulfide 1. Design and Operational Parameters. Air Waste 1994, 44, 863-868. [CrossRef]

120. Chen, Y.; Wang, X.; He, S.; Zhu, S.; Shen, S. The performance of a two-layer biotrickling filter filled with new mixed packing materials for the removal of H2S from air. J. Environ. Manag. 2016, 165, 11-16. [CrossRef]

121. Morgenroth, E.; Schroeder, E.D.; Chang, D.P.Y.; Scow, K.M. Nutrient Limitation in a Compost Biofilter Degrading Hexane. J. Air Waste Manag. Assoc. 1996, 46, 300-308.

122. Zilli, M.; Converti, A.; Lodi, A.; Borghi, M.D.; Ferraiolo, G. Phenol removal from waste gases with a biological filter byPseudomonas putida. Biotechnol. Bioeng. 1993, 41, 693-699. [CrossRef] [PubMed]

123. Ergas, S.J.; Kinney, K.; Fuller, M.E.; Scow, K.M. Characterization of compost biofiltration system degrading dichloromethane. Biotechnol. Bioeng. 1994, 44, 1048-1054. [CrossRef] [PubMed]

124. Chou, M.-S.; Shiu, W.-Z.; Chou, S. Bioconversion of Methylamine in Biofilters. J. Air Waste Manag. Assoc. 1997, 47, 58-65. [CrossRef]

125. Smet, E.; Van Langenhove, H.; Verstraete, W. Isobutyraldehyde as a competitor of the dimethyl sulfide degrading activity in biofilters. Biodegradation 1997, 8, 53-59. [CrossRef] 
126. Tang, H.-M.; Hwang, S.-J.; Hwang, S.-C. Waste Gas Treatment in Biofilters. J. Air Waste Manag. Assoc. 1996, $46,349-354$.

127. Shareefdeen, Z.; Baltzis, B.C. Biofiltration of toluene vapor under steady-state and transient conditions: Theory and experimental results. Chem. Eng. Sci. 1994, 49, 4347-4360. [CrossRef]

128. Arnold, M.; Reittu, A.; von Wright, A.; Martikainen, P.J.; Suihko, M.-L. Bacterial degradation of styrene in waste gases using a peat filter. Appl. Microbiol. Biotechnol. 1997, 48, 738-744. [CrossRef] [PubMed]

129. Hecht, V.; Brebbermann, D.; Bremer, P.; Deckwer, W.-D. Cometabolic degradation of trichloroethylene in a bubble column bioscrubber. Biotechnol. Bioeng. 1995, 47, 461-469. [CrossRef]

130. Hammervold, R.E.; Overcamp, T.J.; Grady, C., Jr.; Smets, B.F.; Hammervold Enotech, R.E.; Thomas Overcamp, C.J.; Grady, C. Sorptive Slurry Bioscrubber for the Control of Acetone. J. Air Waste Manag. Assoc. 2000, 50, 954-960. [CrossRef]

131. Koutinas, M.; Martin, J.; Peeva, L.G.; Mantalaris, A.; Livingston, A.G. An Oil-Absorber-Bioscrubber System To Stabilize Biotreatment of Pollutants Present in Waste Gas. Fluctuating Loads of 1,2-Dichloroethane. Environ. Sci. Technol. 2006, 40, 595-602. [CrossRef] [PubMed]

132. Koutinas, M.; Peeva, L.G.; Livingston, A.G. An attempt to compare the performance of bioscrubbers and biotrickling filters for degradation of ethyl acetate in gas streams. J. Chem. Technol. Biotechnol. 2005, 80, 1252-1260. [CrossRef]

133. Oh, Y.-S.; Bartha, R. Removal of nitrobenzene vapors by a trickling air biofilter. J. Ind. Microbiol. Biotechnol. 1997, 18, 293-296. [CrossRef]

134. Quan, Y.; Wu, H.; Yin, Z.; Fang, Y.; Yin, C. Effect of static magnetic field on trichloroethylene removal in a biotrickling filter. Bioresour. Technol. 2017, 239, 7-16. [CrossRef] [PubMed]

135. Zilli, M.; Nicolella, C. Removal of monochlorobenzene from air in a trickling biofilter at high loading rates. J. Chem. Technol. Biotechnol. 2012, 87, 1141-1149. [CrossRef]

136. Wu, H.; Yin, Z.; Quan, Y.; Fang, Y.; Yin, C. Removal of methyl acrylate by ceramic-packed biotrickling filter and their response to bacterial community. Bioresour. Technol. 2016, 209, 237-245. [CrossRef]

137. Rene, E.R.; Špačková, R.; Veiga, M.C.; Kennes, C. Biofiltration of mixtures of gas-phase styrene and acetone with the fungus Sporothrix variecibatus. J. Hazard. Mater. 2010, 184, 204-214. [CrossRef] [PubMed]

138. Prado, Ó.J.; Veiga, M.C.; Kennes, C. Removal of formaldehyde, methanol, dimethylether and carbon monoxide from waste gases of synthetic resin-producing industries. Chemosphere 2008, 70, 1357-1365. [CrossRef] [PubMed]

139. Pérez, M.C.; Álvarez-Hornos, F.J.; San-Valero, P.; Marzal, P.; Gabaldón, C. Microbial community analysis in biotrickling filters treating isopropanol air emissions. Environ. Technol. 2013, 34, 2789-2798. [CrossRef] [PubMed]

(C) 2019 by the authors. Licensee MDPI, Basel, Switzerland. This article is an open access article distributed under the terms and conditions of the Creative Commons Attribution (CC BY) license (http://creativecommons.org/licenses/by/4.0/). 